\title{
O princípio da "unitas multiplex" do trabalho sob demanda via aplicativos e sua regulação: prenúncio do devir das relações de trabalho pelas lentes da teoria dos sistemas
}

\section{Versão Original}

Tese apresentada à Faculdade de Direito da Universidade de São Paulo para obtenção do título de Doutor em Direito.

Área de concentração: Direito do Trabalho e da Seguridade Social

Orientador: Professor Titular Dr. Nelson Mannrich 
Autorizo a reprodução e divulgação total ou parcial deste trabalho, por qualquer meio convencional ou eletrônico, para fins de estudo e pesquisa, desde que citada a fonte.

\author{
Catalogação da Publicação \\ Serviço de Biblioteca e Documentação \\ Faculdade de Direito da Universidade de São Paulo
}

\title{
Prata, Marcelo Rodrigues
}

O princípio da "unitas multiplex" do trabalho sob demanda via aplicativos e sua regulação: prenúncio do devir das relações de trabalho pelas lentes da teoria dos sistemas ; Marcelo Rodrigues Prata ; orientador Nelson Mannrich -- São Paulo, 2020.

403

Tese (Doutorado - Programa de Pós-Graduação em Direito do Trabalho e Seguridade Social) - Faculdade de Direito, Universidade de São Paulo, 2020.

1. Direito do Trabalho. 2. Parassubordinação. 3. Quarta Revolução Industrial. 4. Teoria dos Sistemas. 5. Princípio da "Unitas Multiplex". I. Mannrich, Nelson, orient. II. Título. 
Nome: PRATA, Marcelo Rodrigues

Título: O princípio da "unitas multiplex" do trabalho sob demanda via aplicativos e sua regulação: prenúncio do devir das relações de trabalho pelas lentes da teoria dos sistemas

Tese apresentada à Faculdade de Direito da Universidade de São Paulo para obtenção do título de Doutor em Direito.

Aprovado em:

Banca Examinadora

Presidente Orientador

Dr.

Instituição:

Julgamento:

Dr.

Instituição:

Julgamento

Dr.

Instituição:

Julgamento

Dr.

Instituição:

Julgamento:

Dr.

Instituição:

Julgamento: 


\section{DEDICATÓRIA}

Dedico este trabalho aos meus pais, Renato e Olinda, minha esposa, Ariana, e meus filhos, Renata e Ignácio, razão do meu viver. 


\section{AGRADECIMENTOS}

Agradeço ao Professor Nelson Mannrich por sua dedicada orientação e incentivo. À inspiração de sempre do Professor José Augusto Rodrigues Pinto e sua adorável esposa, Ana Pinto. Aos meus pais, esposa e filhos que acompanharam e me apoiram nessa trajetória. Aos inestimáveis ensinamentos oferecidos pelos Professores Celso Campilongo, José Eduardo Faria, Orlando Villas Bôas Filho, Rafael Pucci e Ronaldo Porto nas aulas da Faculdade do Largo. Aos colegas do GETRAB-USP pela troca de experiências e fraternal amizade. $E$ aos dedicados servidores da FDUSP pela disponibilidade e atenção. 
"A natureza ama esconder-se" (HERÁcLITO, Fragmento 123). 
PRATA, Marcelo Rodrigues. O princípio da "unitas multiplex" do trabalho sob demanda via aplicativos e sua regulação: prenúncio do devir das relações de trabalho pelas lentes da teoria dos sistemas. 2010. 403 p. Tese (Doutorado em Direito) - Faculdade de Direito, Universidade de São Paulo, São Paulo, 2010.

\section{RESUMO}

A presente tese tem por objetivo principal sugerir a criação do "princípio da unitas multiplex do trabalho sob demanda via aplicativos", bem assim aventar diretrizes para regulação da modalidade mencionada. Aliás, a relação de trabalho sob demanda via aplicativos surge como prenúncio do que acontecerá ao Direito do Trabalho em seu desafio para se (auto)adaptar diante das tendências de transformações que a Quarta Revolução Industrial traz em seu bojo. A defesa da presente tese exige abordar o problema das dimensões, "in abstracto", da natureza jurídica da relação de trabalho sob demanda na Pós-Modernidade, bem como a investigação quanto à possibilidade de reduzi-las a uma única espécie. O enfrentamento do tema proposto impõe definirse o que se entende por trabalho sob demanda via aplicativos. A propósito, a revisão dos elementos essenciais da relação de trabalho faz-se aqui necessária. Aliás, as dimensões, em abstrato, da natureza jurídica da relação em comento foram examinadas, ressaltando-se sua diferença específica. Por sinal, aí se impôs um estudo sobre o instituto da parassubordinação. Além disso, uma pesquisa sobre a hipótese do pluralismo jurídico como alternativa à anomia e ao ativismo judicial ou, pior, à politização da magistratura no Brasil revelou-se necessária. Finalmente, as possibilidades de transformação das relações de trabalho na Pós-Modernidade foram apontadas, bem como diretrizes para regulação trabalho sob demanda via aplicativos. Noutro giro, a metodologia empregada aqui é a da teoria dos sistemas sociais na versão luhmanniana, considerando-se que esta última oferece ao jurista prático uma ampla perspectiva problematizante das questões enfrentadas pela Dogmática Trabalhista. Assim, foi possível especular a respeito do futuro do trabalho com o distanciamento necessário.

Palavras-chave: Direito do Trabalho. Parassubordinação. Quarta Revolução Industrial. Teoria dos Sistemas. Princípio da unitas multiplex. 
PRATA, Marcelo Rodrigues. The unitas multiplex principle of on-demand work via apps and its regulation: prediction the becoming of labor relations through the lenses of systems theory. 2010. 403 p. Thesis (Doctorate in Law) - Faculdade de Direito, Universidade de São Paulo, São Paulo, 2010.

\begin{abstract}
The present Thesis has as main objective the creation of the unitas multiplex principle of on-demand work via apps, as well as the development of guidelines for the regulation of the mentioned modality. In fact, the on-demand employment relationship via apps is a foreshadowing of what will happen to Labor Law in its challenge to (self)adapt to the changing trends that the Fourth Industrial Revolution brings in its wake. The defense of the present thesis requires addressing the problem of the "in abstracto" dimensions of the juridical nature of the Postmodernity labor relationship on demand, as well as investigating the possibility of reducing them to a single species. The confrontation of the proposed theme demands defining on-demand work via apps. By the way, the revision of the essential elements of the working relationship is necessary. Incidentally, the abstract dimensions of the legal nature of the relationship under review are examined, highlighting the latter's specific differences. Incidentally, there is a study on the institute of parasubordination. In addition, research on the hypothesis of legal pluralism as an alternative to anomie and judicial activism or, worse, the politicization of the Judiciary in Brazil is proven necessary. Finally, the possibilities of transformation of labor relations in Postmodernity are pointed out, as well as guidelines for regulating work on demand via applications. In another turn, the methodology employed here is that of the Social Systems Theory in the Luhmannian version, considering that the latter offers the practical jurist a broadly critical perspective on the issues facing Labor Dogmatics. Thus, it is possible to speculate about the future of work with the necessary distance.
\end{abstract}

Keywords: Labor Law. Parasubordination. Fourth Industrial Revolution. Systems Theory. Unitas multiplex principle. 


\section{SUMÁRIO}

1 INTRODUÇÃO

2 A TEORIA DOS SISTEMAS COMO MÉTODO DE ANÁLISE DAS

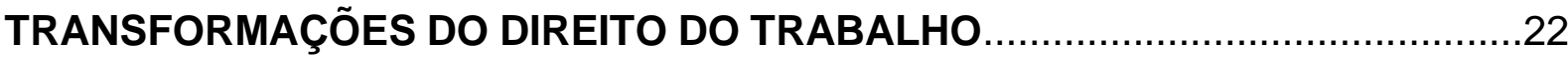

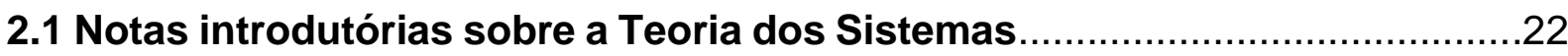

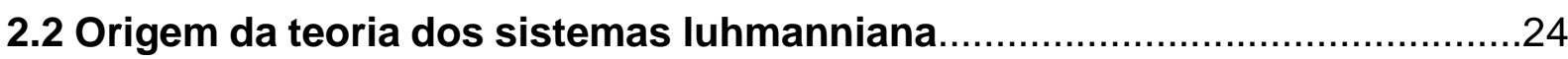

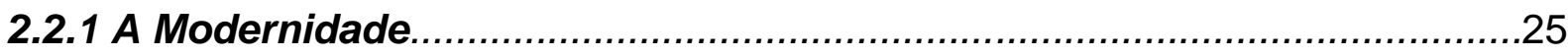

2.2.2 Escorço histórico da teoria dos sistemas Iuhmanniana.............................26

2.3 A arquitetura semântica da teoria dos sistemas luhmanniana.........................30

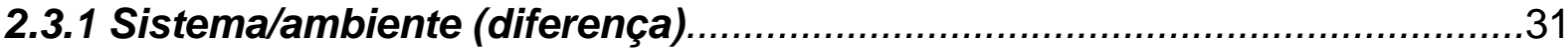

2.3.2 Estruturas, limites, comunicação, dupla contingência, expectativas de

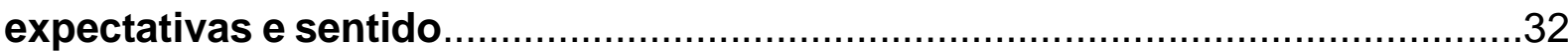

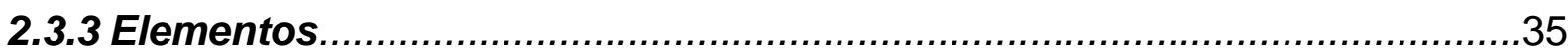

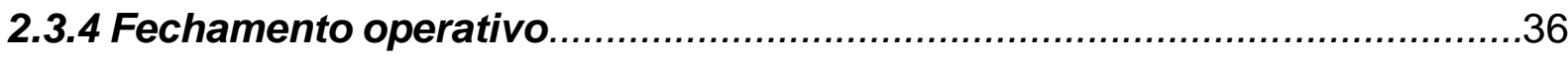

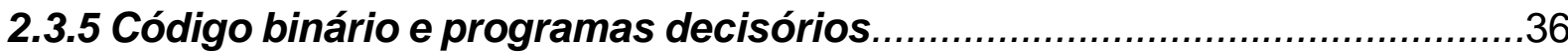

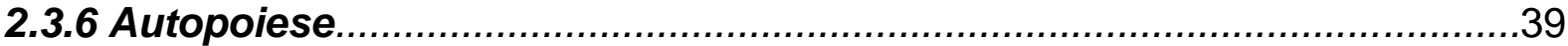

2.3.7 Acoplamento estrutural, abertura cognitiva, ruído e autoirritação...............41

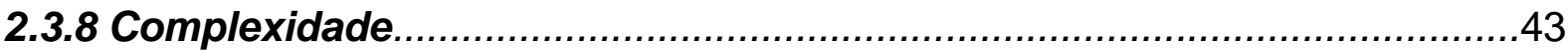

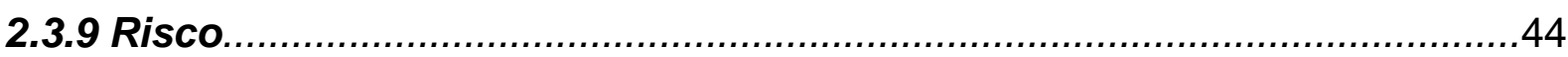

2.3.10 Tempo

2.3.11 Aprendizagem, adaptação e evolução....................................................46

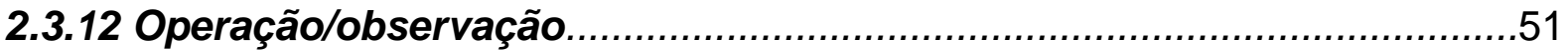

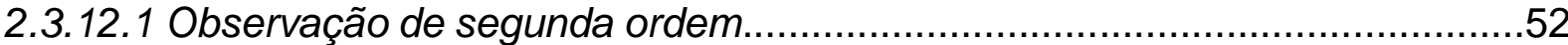

2.3.13 Inclusão/exclusão. Conceito de pessoa. Organizações.......................... 53

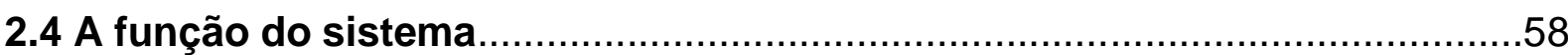

2.5 A sociedade como sistema

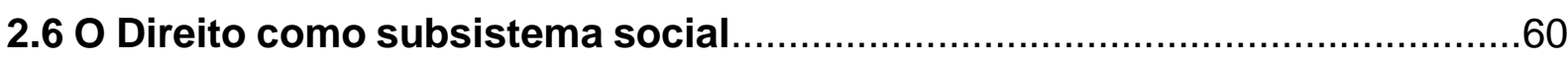

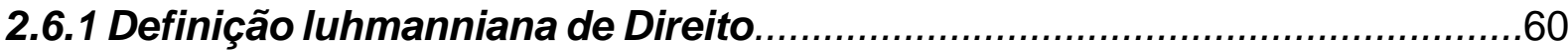

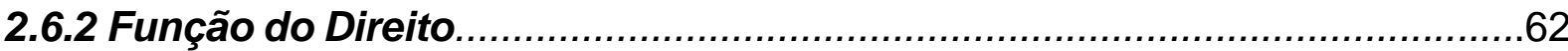

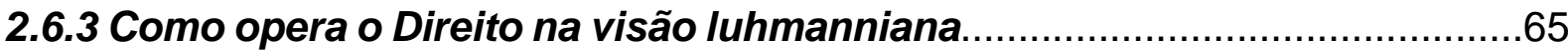

2.6.3.1 O Direito como sistema imunológico da sociedade .......................................68 
2.6.4 A justiça como fórmula de contingência (decisão mais adequada ao

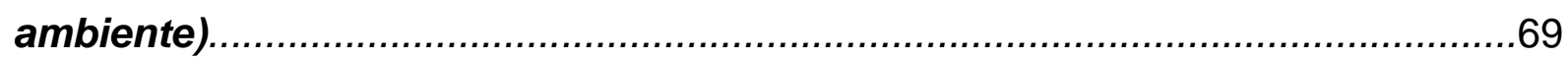

2.6.5 Posição dos tribunais no subsistema jurídico (centro/periferia).................71

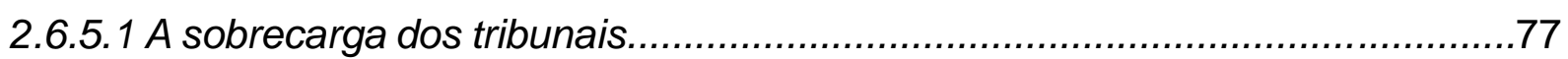

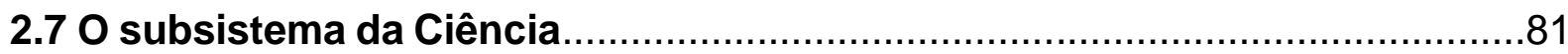

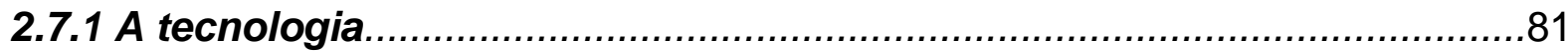

2.7.2 A relação entre Ciência e tecnologia para a teoria dos sistemas.................83

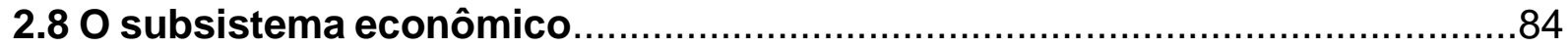

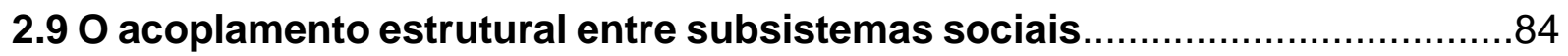

2.9.1 O acoplamento estrutural entre Direito e Ciência...................................... 86

2.9.2 0 acoplamento estrutural entre Direito e Economia..................................87

2.9.3 0 acoplamento estrutural entre Direito e Política......................................88

2.10 Os reflexos do tempo nos subsistemas sociais.......................................

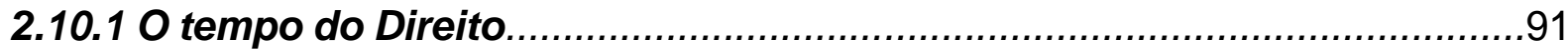

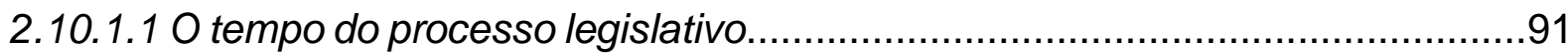

2.10.1.1.1 O exemplo da Reforma Trabalhista de 2017........................................93

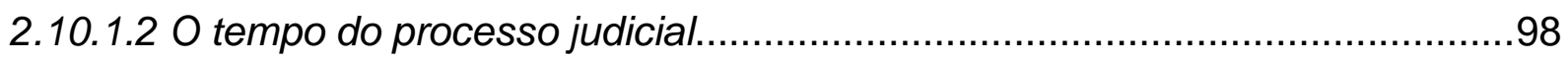

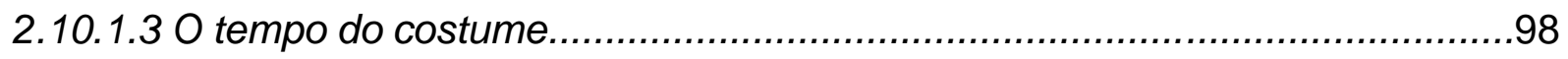

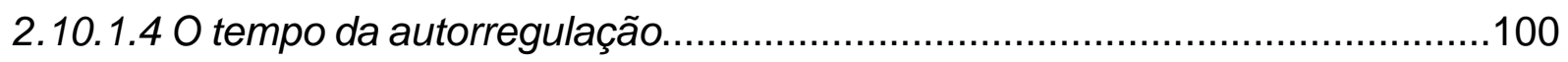

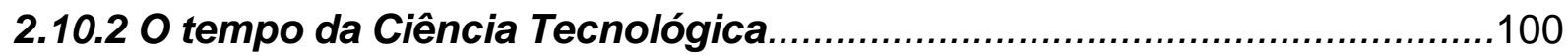

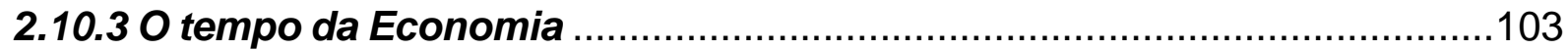

2.110 problema da assincronia entre subsistemas sociais ...........................105

3 PANORAMA DO TRABALHO SOB DEMANDA VIA APLICATIVOS..................107

3.1 Fenômenos da "gig-economy" e da economia compartilhada.....................107

3.1.2 Distinção entre "crowdwork" e "on-demand work via apps"....................109

3.2 Definição de plataforma de trabalho digital..............................................111

3.2.1 Natureza jurídica das plataformas......................................................112

3.3 Definição de gerenciamento algorítmico .............................................112

3.3.1 0 papel do gerenciamento algorítmico no devir do trabalho......................114

3.4 Exemplos de prestadoras de serviços demandados via aplicativos............115

3.5 Escorço histórico sobre a origem, evolução e importância socioeconômica

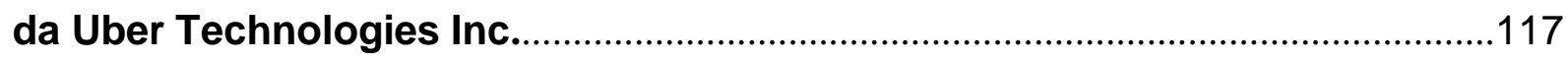

3.5.1 Qual a natureza jurídica da Uber Technologies Inc. ? ..............................121

3.6 A operação informal das startups e o direito vivo.....................................127 
3.7 Impactos positivos e negativos da atividade de transporte via aplicativos. 130 3.8 Vantagens e desvantagens do trabalho sob demanda via aplicativos.........135 3.8.1 Vantagens da contratação de trabalho sob demanda via aplicativos........136 3.8.2 Desvantagens da contratação trabalho sob demanda via aplicativos.......138 4 O TRILEMA DA NATUREZA JURÍDICA DA RELAÇÃO DE TRABALHO SOB

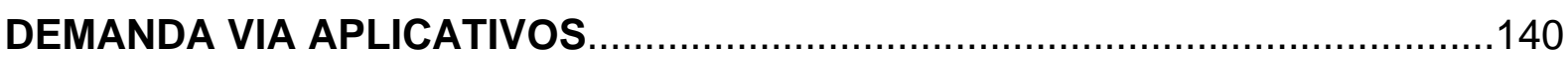

4.1 Nota introdutória ao problema da natureza jurídica trabalho sob demanda via aplicativos. .140

4.1.1 Definição de trabalho sob demanda via aplicativos 144

4.2 A hipótese de caracterização do trabalho sob demanda via aplicativos como contrato de trabalho. .145

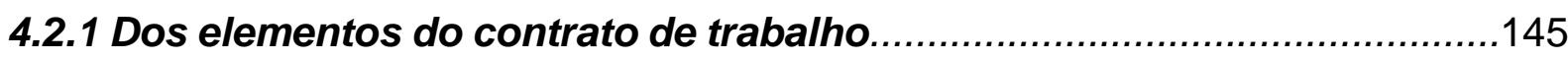

4.2.1.1 Do trabalho prestado por pessoa física ou natural......................................146

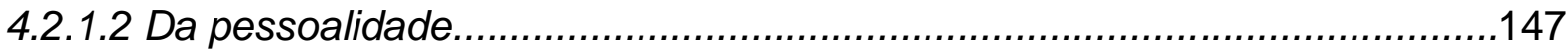

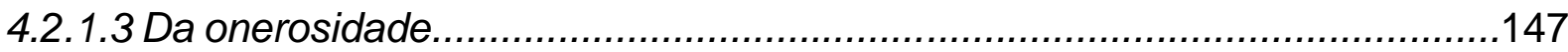

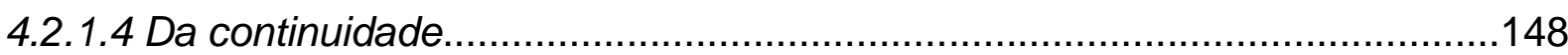

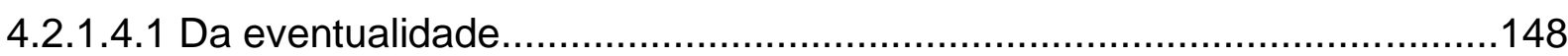

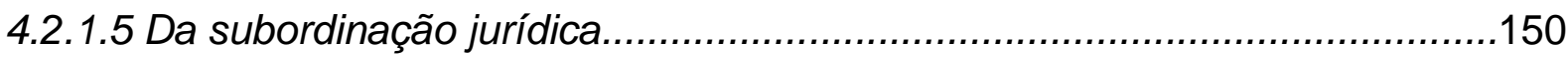

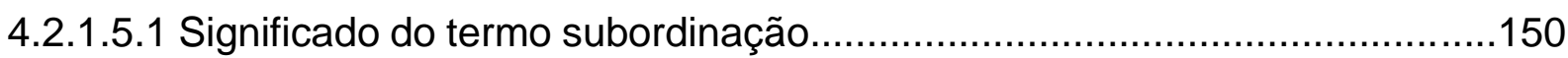

4.2.1.5.2 Conceito de subordinação jurídica.......................................................151

4.2.1.5.3 Natureza jurídica do instituto da subordinação jurídica............................155

4.2.1.5.4 Dimensões da subordinação jurídica: .................................................155

a) dimensão de natureza subjetiva da subordinação jurídica;......................155

b) dimensão de natureza objetiva da subordinação jurídica;.........................156

c) dimensão de natureza estrutural da subordinação jurídica.......................157

4.2.1.5.5 Evolução do conceito de subordinação jurídica.........................................160

4.2.1.5.6 Distinção entre dependência e subordinação jurídica................................162

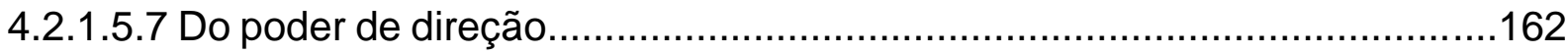

4.2.1.5.8 O poder disciplinar como elemento da subordinação jurídica......................163

4.2.1.5.9 Impactos da Revolução 4.0 no conceito de subordinação jurídica...............163

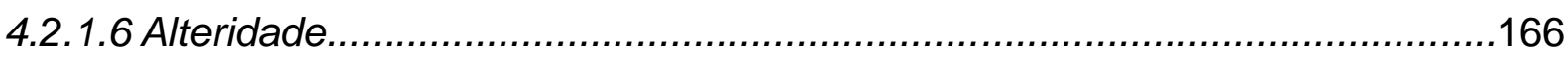

4.2.1.7 Da possibilidade de configuração de vínculo empregatício no trabalho sob

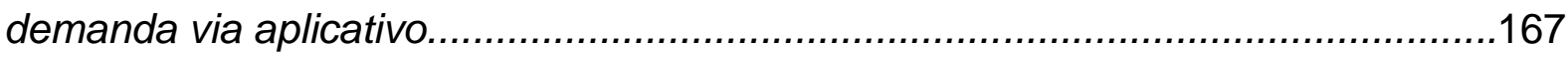

4.2.1.7.1 Definição de contrato de trabalho sob demanda via aplicativos..................168 
4.3 A hipótese de trabalho sob demanda via aplicativos como forma de prestação de serviço autônomo................................................................171

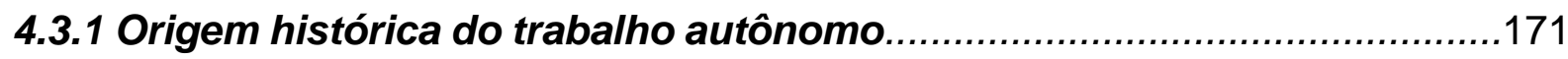

4.3.2 Definição de trabalho autônomo e distinção do subordinado....................171

4.3.3 O autônomo na Reforma Trabalhista...................................................173

4.3.3.1 Natureza jurídica da presunção criada pelo art. 442-B da CLT .....................174

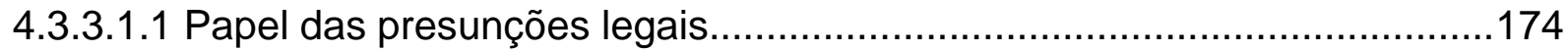

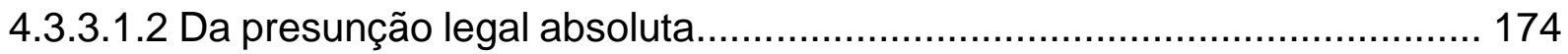

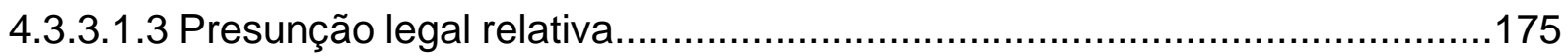

4.3.3.1.4 Limites das presunções criadas por lei..............................................175

4.3.3.1.5 Constitucionalidade da determinação legal da natureza da contratação de

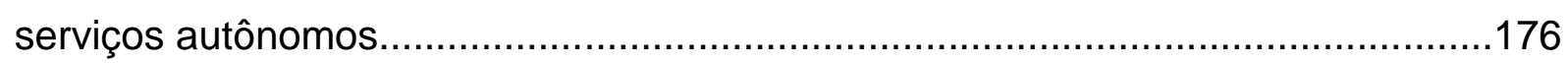

4.3.3.2 Formalidades legais exigidas no contrato de trabalho de autônomo..............178

4.3.3.3 Exclusividade no contrato de trabalho autônomo........................................179

4.3.3.4 Continuidade no contrato de trabalho autônomo.......................................180

4.3.4 Seria autônomo ou subordinado o trabalho sob demanda via aplicativos? 181

4.3.4.1 O trabalhador em plataforma como profissional liberal................................189

4.3.4.2 O trabalhador em plataforma como microempreendedor individual (MEI)....189

4.3.4.2.1 Regulamentação do transporte remunerado privado individual de passageiros pela Lei $\mathrm{n}^{\circ}$ 13.640/2018 e a "uberização"..............................................192

4.3.4.3 O trabalhador em plataforma como sócio de cooperativa.............................196

4.3.4.4 O trabalhador em plataforma como integrante de sociedade empresária......197

4.3.5 O problema da fraude na contratação do trabalhador autônomo...............198

4.3.6 Definição do contrato de prestação de serviço autônomo sob demanda via

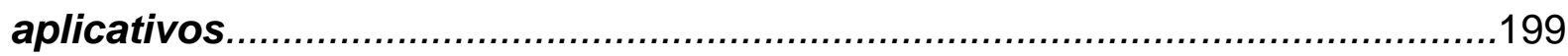

4.4 A hipótese do trabalho sob demanda via aplicativos como

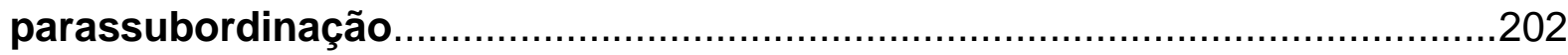

4.4.1 Conceito e natureza jurídica da parassubordinação..................................204

4.4.2 A parassubordinação no Direito do Trabalho brasileiro............................206

4.4.3 A parassubordinação e o trabalhador autônomo economicamente dependente no Direito do Trabalho comparado.............................................20

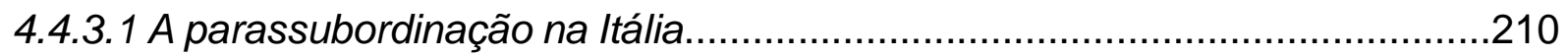

4.4.3.1.1 Colaboração coordenada e continuativa ("co.co.co."): .............................210 


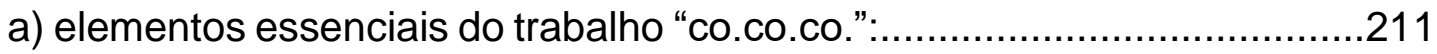

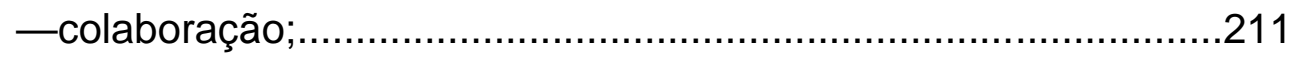

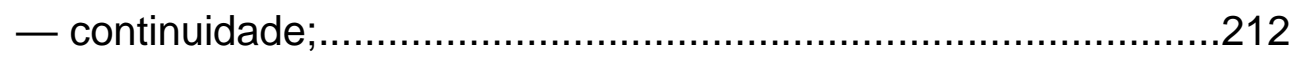

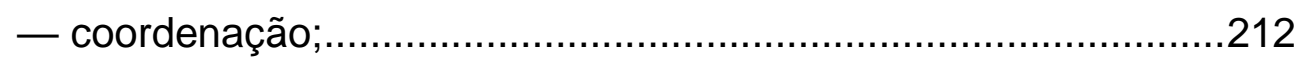

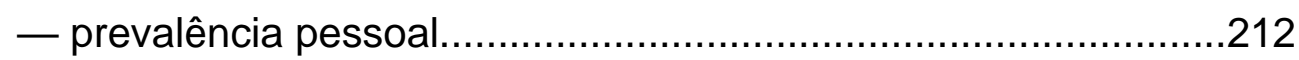

b) espécies de trabalhadores sob a modalidade de "co.co.co.".....................213

— agentes e representantes comerciais; ....................................213

— outras relações de coordenação...............................................213

4.4.3.1.2 Contrato de colaboração por projeto ("co.co.pro") …................................214

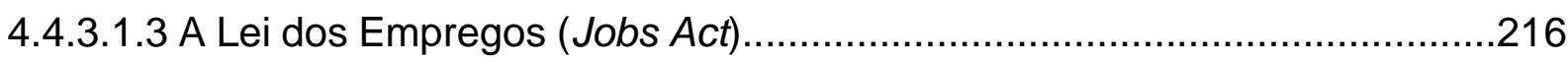

4.4.3.1.4 Benefícios garantidos aos parassubordinados na Itália..........................217

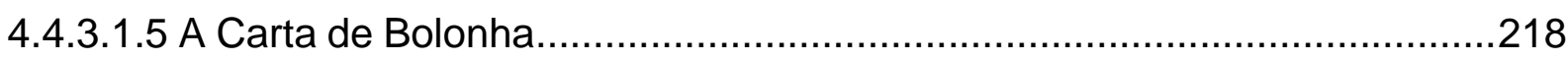

4.4.3.1.6 Tutela de entregadores de refeições italianos......................................220

4.4.3.2 A parassubordinação na Espanha............................................................ 221

4.4.3.2.1 Direitos do autônomo economicamente dependente...............................222

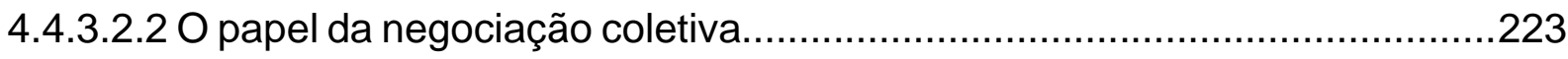

4.4.3.2.3 Proposta de criação da figura do TRADE digital.......................................224

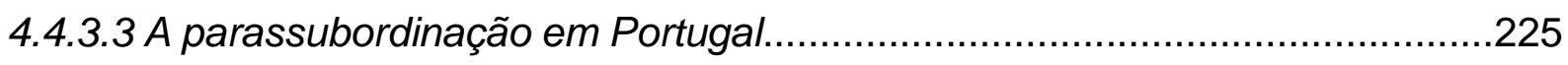

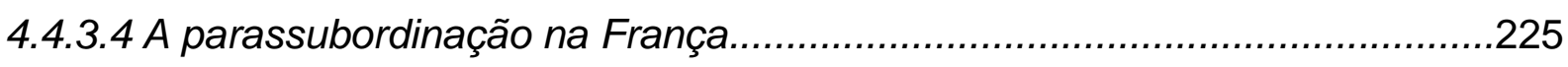

4.4.3.4.1 Autônomos que utilizem plataformas eletrônica........................................227

4.4.3.4.2 Projeto de criação da Carta Social......................................................229

4.5 Moldura teoricamente mais adequada ao trabalho sob demanda via

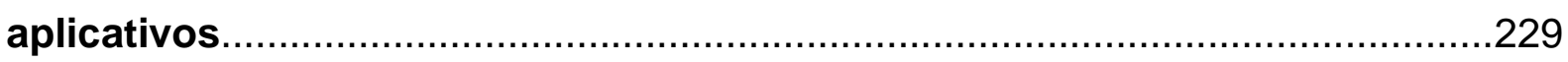

4.5.1 Definição de trabalho parassubordinado sob demanda via aplicativos....232 4.6 Quid juris diante da ausência de positivação do trabalho parassubordinado?....................................................................................233

4.6.1 É possível aplicar o Direito Comparado no Brasil quanto à figura da

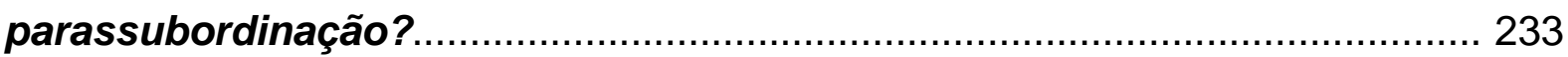

50 PLURALISMO JURÍDICO COMO ALTERNATIVA À DIACRONIA ENTRE SUBSISTEMAS E À ANOMIA BRASILEIRA

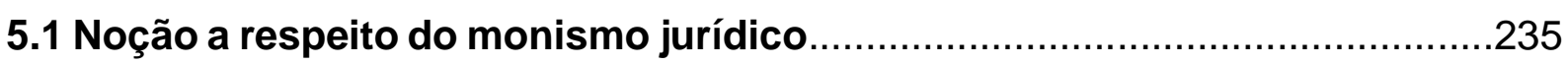

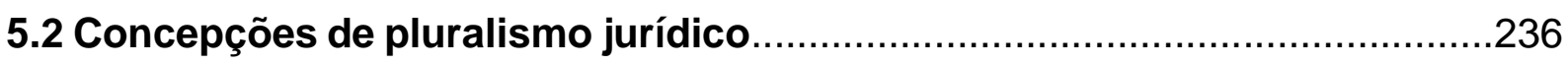

5.3 Evolução do instituto do pluralismo jurídico ............................................237 
5.4 Globalização, Pós-Modernidade, pluralismo jurídico e o Direito do Trabalho. 239

5.5 A contribuição do Direito do Trabalho ao pluralismo jurídico ......................244

5.60 problema brasileiro do presidencialismo de coalisão...............................245

5.70 pluralismo jurídico no Direito do Trabalho no Brasil atual.......................246

5.8 A importância do pluralismo diante da ausência de sincronicidade ............248

5.90 pluralismo jurídico como alternativa viável à anomia brasileira, inflação legislativa, ativismo judicial e à politização da magistratura

5.100 pluralismo jurídico ofereceria alternativas à anomia reinante quanto ao

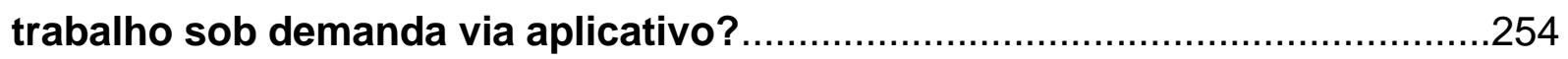

6 DIMENSÕES DA REVOLUÇÃO INDUSTRIAL. .260

6.1 Brevíssima nota sobre o processo de destruição criativa schumpeteriano 260

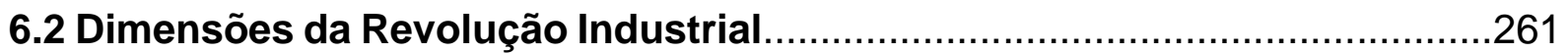

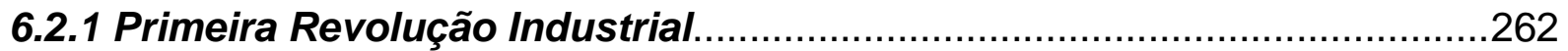

6.2.1.1 Reflexos da Primeira Revolução Industrial no Direito do Trabalho................263

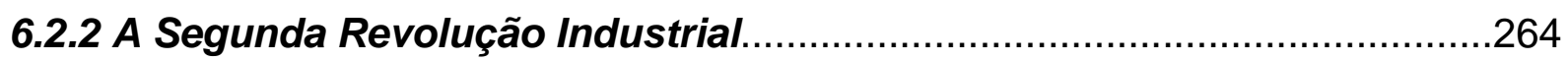

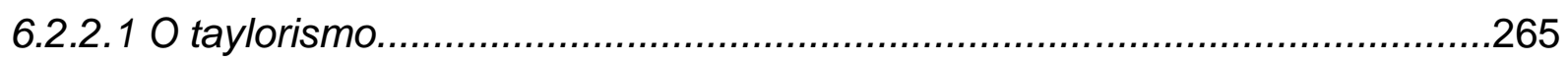

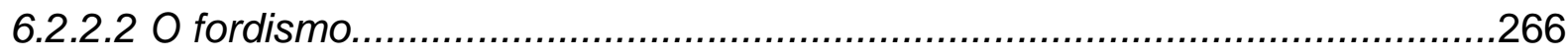

6.2.2.3 Efeitos da Segunda Revolução Industrial na órbita trabalhista.....................268

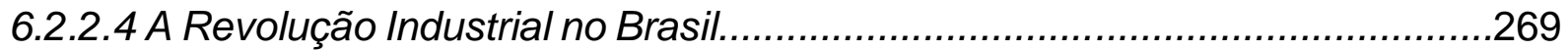

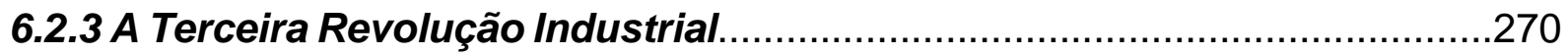

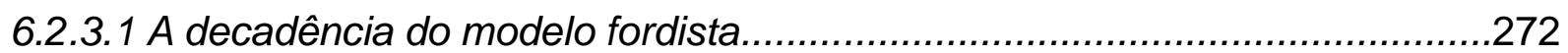

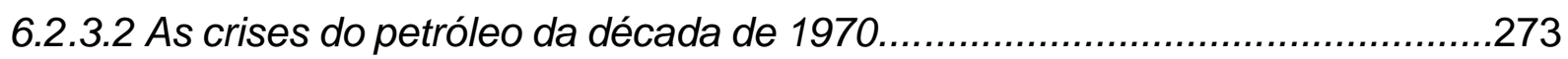

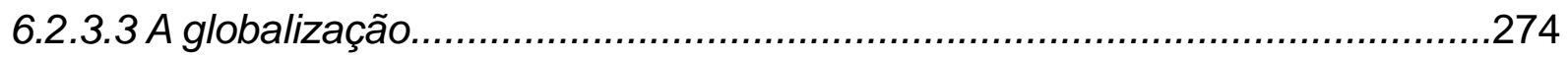

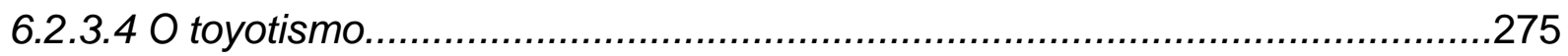

6.2.3.5 A crise das hipotecas "subprime" (2007/2008) ......................................277

6.2.3.6 Impactos da Terceira Revolução Industrial no trabalho................................278

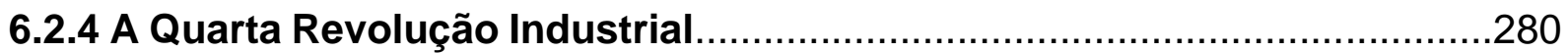

6.2.4.1 Importância dos algoritmos e da inteligência artificial.................................282

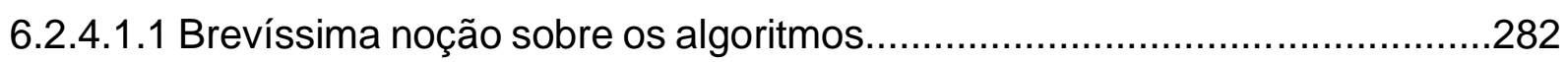

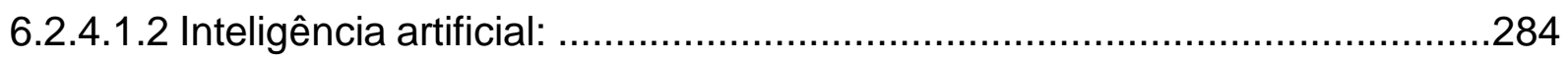

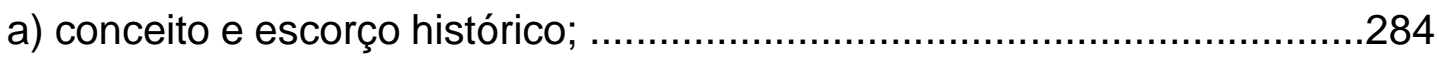

b) hipótese de superação da inteligência humana pela artificial....................288 
6.2.4.2 Impactos da Quarta Revolução Industrial na esfera trabalhista. .289

6.2.5 A proteção constitucional em face da automação....................................294

6.3 Riscos inerentes à tecnologia disruptiva .................................................

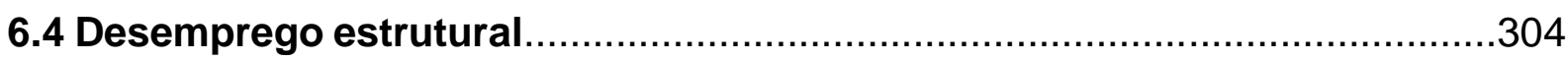

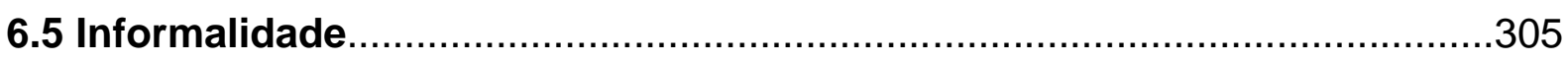

6.6 A ameaça de desintegração do Direito do Trabalho.....................................306

7 O PRINCÍPIO DA UNITAS MULTIPLEX DO TRABALHO SOB DEMANDA VIA

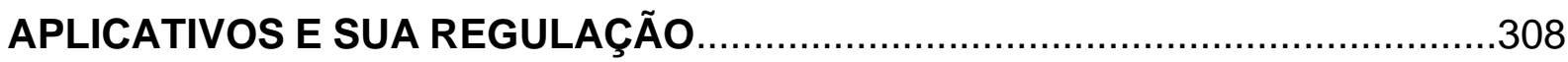

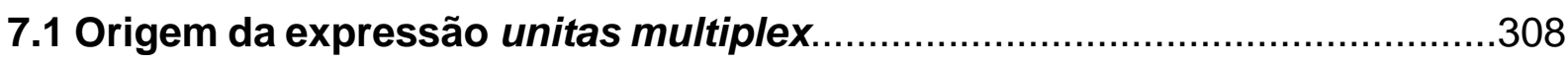

7.2 A aplicação jurídico-acadêmica do princípio unitas multiplex.......................310

7.3 A unitas multiplex e a teoria dos sistemas luhmanniana..............................312

7.4 A complexidade na unidade do trabalho sob demanda via aplicativos........314

7.4.1 A relação de trabalho sob demanda via aplicativos e o Código de Defesa

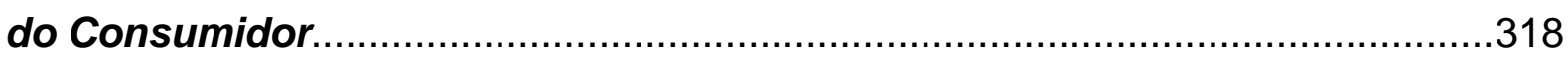

7.4.1.1 Da relação de trabalho em sentido amplo e estrito.................................319

7.4.1.1.1 Noção de trabalho............................................................................

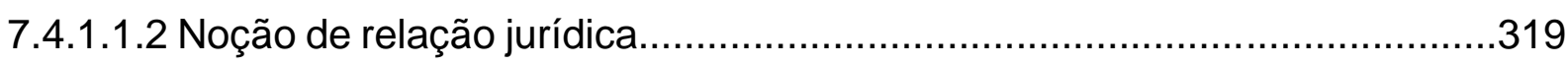

7.4.1.1.3 Noção de relação jurídica trabalhista individual........................................320

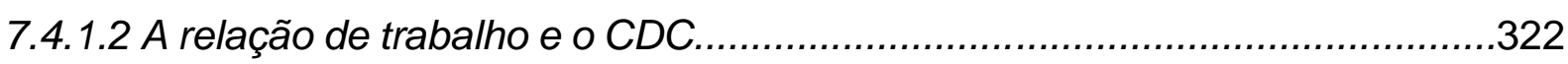

7.4.1.2.1 Distinção entre relação de trabalho e relação de consumo..........................325

7.4.1.3 A relação de trabalho sob demanda via aplicativos como "unitas multiplex" e

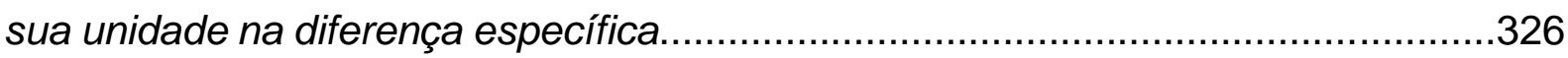

7.5 0 trabalho sob demanda via aplicativos como prenúncio do devir das

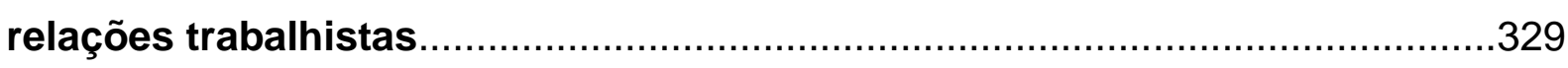

7.6 A parassubordinação como alternativa...................................................330

7.7 Posição contrária à criação de terceira categoria de trabalhadores..............335

7.8 A realidade das relações de trabalho brasileiras e a urgência de solução...336 7.9 Da possibilidade de reconhecimento de vínculo empregatício com a plataforma.

7.9.1 Da possibilidade de reconhecimento de vínculo empregatício com o

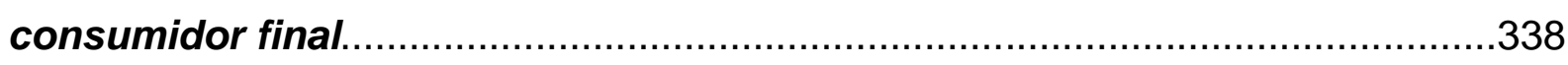

7.9.2 0 que desejam os trabalhadores sob demanda via aplicativos?...............339

7.100 combate à discriminação do trabalhador sob demanda via aplicativos. 343

7.11 O pluralismo jurídico como alternativa viável à anomia reinante 
7.12 Projetos de lei sobre o trabalho via plataforma digital..............................345

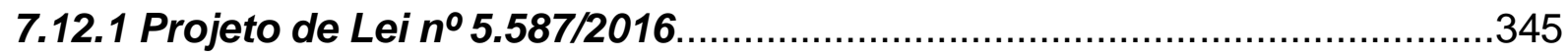

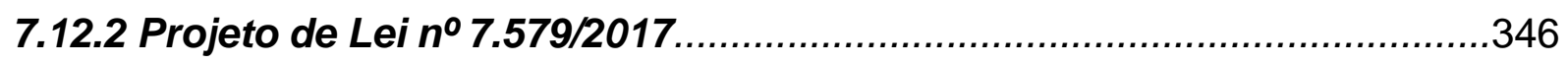

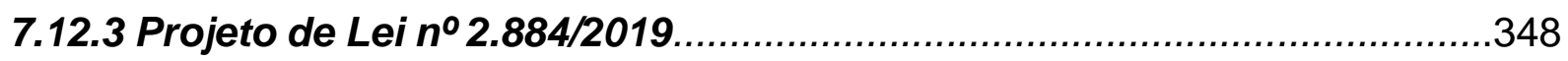

7.12.4 Projeto de Lei Complementar no 521/2018.........................................

7.13 Proposta de diretrizes sobre o trabalho sob demanda via aplicativos.......349

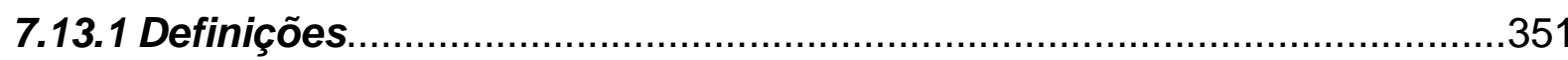

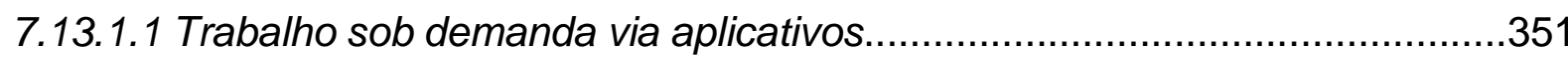

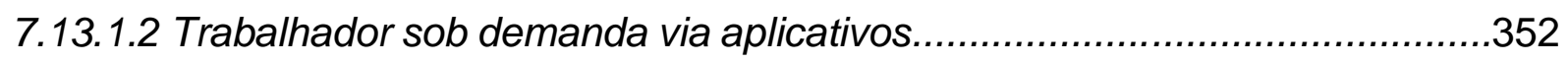

7.13.1.3 Administradora de plataforma de trabalho digital.....................................352

7.13.1.4 Trabalhador sob demanda via aplicativos autônomo economicamente

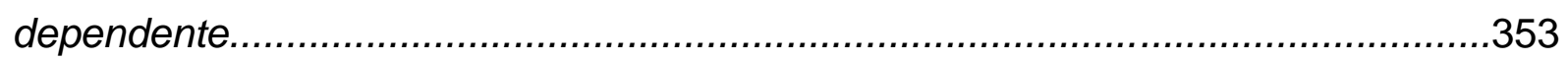

7.13.2 Direitos do trabalhador sob demanda via aplicativos..............................354

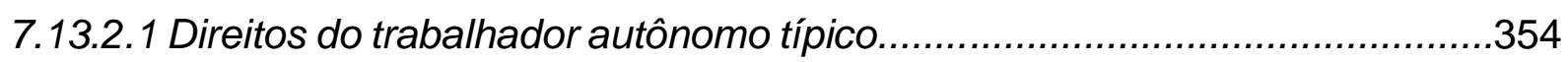

7.13.2.2 Direitos do trabalhador parassubordinado ou autônomo economicamente

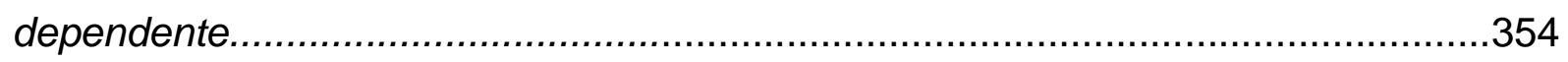

7.14 Hipótese de fraude na prestação de serviços sob demanda via

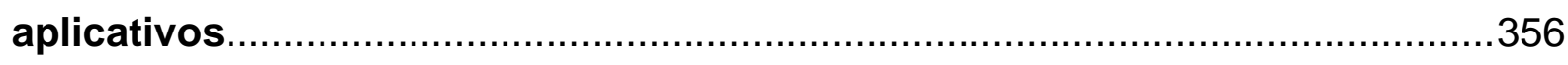

7.15 A importância do papel social das plataformas de trabalho digitais..........357

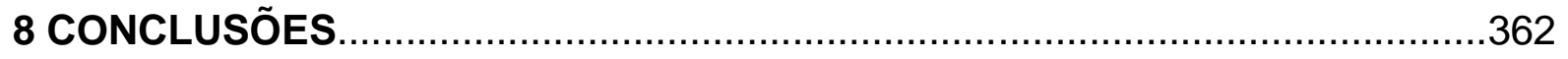

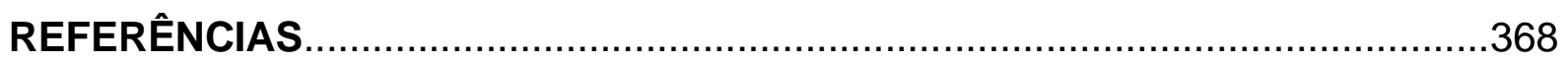




\section{INTRODUÇÃO}

Conta uma lenda medieval — reproduzida por GIOVANNI PAPINI — que o filósofo e teólogo SANTO AgostinHo (354-430), considerado um dos Padres da Igreja, teria encontrado ao caminhar pela praia um menino que corria até o mar com uma colherinha, a enchia d'água e após a esvaziava em um buraco escavado na areia. Curioso, ele indagou ao garoto o que este fazia, que, por sua vez, Ihe respondeu pretender colocar o mar inteiro ali naquela covinha. O Bispo de Hipona então lhe disse sorrindo ser isso impossível. O pequeno anjo the respostou que era mais fácil para este verter o mar naquele buraquinho do que AGOSTINHO conseguir entender a Divina Trindade.

A propósito, esse conto nos faz lembrar a importância da fé - seja religiosa, seja laica - como elemento propulsor dos avanços da humanidade. Evidentemente, aqui não se cuida de fanatismo, mas de crença racional em algo que nos possa libertar das amarras do pessimismo, muita vez imposto por um presente desolador. Posto que não seja razoável defender-se uma ideia completamente divorciada do que sugerem os fatos, é forçoso reconhecer que o ceticismo, embora aparentemente lógico, pode conduzir ao niilismo e desespero. ${ }^{1}$

Por sinal, essa mesma fábula igualmente ilustra a noção de que há mistérios aparentemente insondáveis que, ipso facto, não podem ser compreendidos pelos métodos tradicionais, ou seja, sem a mobilização do "pensamento complexo". Há problemas, como a natureza jurídica, "in abstracto", do trabalho sob demanda via aplicativos e suas implicações, que desafiam ferramentas epistemológicas sofisticadas nas quais a imaginação criativa é elemento essencial.

De tal sorte, nutrindo fortemente a esperança de que o Direito do Trabalho ainda possa representar - em plena Era da Quarta Revolução Industrial - um instrumento de segurança e aperfeiçoamento para as relações de trabalho, mas

\footnotetext{
1 "A Ciência sem religião é aleijada, a religião sem a Ciência é cega". (Einstein: vida e pensamentos. São Paulo: Martin Claret, 2002, p. 47.).
} 
cientes dos incomensuráveis desafios que a quadra atual nos reserva, é que enfrentamos o problema da natureza, em abstrato, da relação de trabalho sob demanda via aplicativos, à luz do princípio da unitas multiplex. Além disso, sugerimos uma regulação a respeito, bem como aventamos a possibilidade de transformação que esta nova e complexa forma de relação de trabalho prenuncia. Tudo isso nas pegadas do método proposto pela teoria dos sistemas de matriz luhmanniana.

Aliás, a segunda seção desta tese é denominada: A Teoria dos Sistemas como Método de Análise das Transformações do Direito do Trabalho. Por sinal, frise-se, de logo, que a presente tese cuida de tema de interesse primordialmente da Doutrina Trabalhista. Por conseguinte, não há aqui a mínima pretensão de contribuir-se criticamente para o aprimoramento da teoria dos sistemas sociais na versão luhmanniana. Cuida-se neste estudo apenas de um tentâmen de se mobilizar este fascinante corpo de ideias como ferramenta epistemológica, mas se mirando sobretudo o jurista prático. A propósito, pugna ANDRÉ-JEAN ARNAUD por uma Ciência do Direito "total", isto é, baseada na pesquisa interdisciplinar, aí abarcada a Dogmática Jurídica, a Filosofia do Direito e a Sociologia Jurídica.

Por sinal, tendo em vista que a teoria dos sistemas ainda não está suficientemente difundida entre nós, esclareça-se que para compreender a hipercomplexa sociedade atual, ela parte da ideia altamente abstrata de que esta última é um sistema, por sua vez, formado por subsistemas sociais - a exemplo do Direito, da Política, da Economia, da Ciência etc. De outro lado, cada sistema parcial da sociedade é independente do outro, ou seja, eles são operacionalmente fechados, o que dificulta a comunicação entre si, muito embora sejam também cognitivamente abertos aos ruídos externos, o que, por seu turno, permite-Ihes aprendizagem e assim sua (auto)adaptação ao ambiente.

Por outro lado, a evolução da Ciência Tecnológica traz cada vez mais complexidade à vida social e isso em um ritmo inusitado que o Direito tem dificuldade de acompanhar, pois cada um dos subsistemas tem seu próprio tempo de aprendizagem e (auto)adaptação. Aliás, a falta de sincronicidade entre eles gera risco, impondo a criação alternativas capazes de minimizá-lo. Tudo isso será desenvolvido didaticamente no primeiro capítulo. 
Noutro giro, a teoria dos sistemas auxilia o pesquisador a articular logicamente suas ideias e permite ainda uma "observação da observação". Por outras palavras, a observação dos operadores do microssistema do Direito do Trabalho sobre o problema do trabalho sob demanda via aplicativos - limitada pela moldura do ordenamento jurídico - é, por sua vez, igualmente observada pela Teoria mobilizada (observação de segunda ordem). Assim, é possível especular-se com maior liberdade sobre o devir do trabalho em virtude das constantes transformações ocorridas na PósModernidade com maior respaldo epistemológico.

Já na terceira seção, intitulada Panorama do Trabalho sob Demanda Via Aplicativos, como o próprio título indica, cuidamos de oferecer uma visão geral sobre a atualidade dessa modalidade de serviço. Referimo-nos a empresas de tecnologia como, e.g., Click Babá, GetNinjas, Loggi, Rappi, DogHero, Jurídico Certo e naturalmente à Uber, na qual concentraremos nosso foco, haja vista que se trata insofismavelmente da empresa mundialmente mais bem-sucedida a oferecer aplicativo para o serviço de sob demanda.

Por sinal, faremos um escorço histórico sobre a evolução meteórica da Uber, mencionando algumas de suas conquistas e desafios mais representativos. A propósito, digno de nota é sua capacidade de estimular transformações nos sistemas jurídicos dos países nos quais se instala, à revelia de regulamentação específica, nos fazendo lembrar da teoria do direito vivo de EUGEN EHRLICH.

Noutro giro, faremos um rápido balanço a respeito das vantagens e desvantagens do trabalho sob demanda via aplicativos. Vale dizer, citaremos os prós da geração de emprego e renda, redução do custo da mão de obra, do barateamento das tarifas e da comodidade para os consumidores. De outro lado, mencionaremos também a situação de insegurança jurídica em que se encontram principalmente os trabalhadores autônomos economicamente dependentes, carentes de proteção social própria.

No que toca à quarta seção: O Trilema da Natureza Jurídica do Trabalho sob Demanda pela Internet, trataremos de traçar um panorama sobre os elementos do 
contrato de trabalho que permitem sua caracterização como tal, buscando explorar a possibilidade de enquadrar o trabalho sob demanda via aplicativos como espécie de contrato de trabalho. Além disso, procederemos ao tentâmen de analisá-lo como forma de prestação de serviço autônomo. Finalmente, aventaremos a possibilidade de classifica-lo como hipótese de parassubordinação.

Aliás, este último instituto carece de regulamentação em nosso país e, por conseguinte, de volume de pesquisas doutrinárias e fontes jurisprudenciais a respeito. Por isso mesmo faremos um estudo comparativo sobre a figura em comento nalguns países de tradição jurídica semelhante à nossa - Portugal, Espanha, Itália e França. Mais adiante especulamos se a parassubordinação, tal qual aplicada na Europa Continental, é a moldura mais adequada ao trabalho sob demanda via internet, levando-se em conta ainda a falta de positivação do trabalho parassubordinado em nosso país.

Por sua vez, quanto à quinta seção: O Pluralismo Jurídico como Alternativa à Diacronia entre Subsistemas e à Anomia Brasileira, cuidaremos da questão da falta de sintonia entre sistemas parciais da sociedade, anomia brasileira, inflação legislativa, ativismo judicial e politização da magistratura. Além disso, trataremos, ainda que mui brevemente, da gravíssima crise política que aflige o país. Isso nos obrigará a encarar o consequente risco de desintegração do Direito do Trabalho por falta de aprendizagem e adaptação, sendo, nessa hipótese, seu objeto absorvido por outras disciplinas.

Já quanto à sexta seção: Dimensionamento da Revolução Industrial e Critérios para Regulamentação do Trabalho sob Demanda via Aplicativos pretendemos enfrentar diversos tópicos pertinentes às transformações do Direito do Trabalho impostas pela Economia e pela Ciência Tecnológica. Assim, discorreremos, posto que en passant, sobre a destruição criativa schumpeteriana, cujos ciclos foram acelerados pela Quarta Revolução Industrial e os riscos inerentes à tecnologia disruptiva. Os problemas do desemprego estrutural, da informalidade, das fraudes nas relações de trabalho serão também enfrentados. 
Finalmente, na sétima seção: O Princípio da Unitas Multiplex do Trabalho sob Demanda via Aplicativos e sua Regulação a tese propriamente dita já está madura para ser exposta, haja vista que explicado o método epistemológico da teoria dos sistemas luhmanniana, bem assim todo cenário socioeconômico, científico e tecnológico, político e jurídico no qual surge o trabalho sob demanda via aplicativos. Isso de modo a bem articular as ideias e o contexto que levam à sugestão do princípio referido, bem assim propor diretrizes para regulação da modalidade de relação de trabalho mencionada. Aliás, frise-se, defende-se aqui que o trabalho sob demanda via aplicativos surge como prenúncio do que acontecerá ao Direito do Trabalho em seu desafio para se (auto)adaptar diante das tendências de transformações que a Quarta Revolução Industrial traz em seu bojo. 


\section{CONCLUSÕES}

Os desígnios inescrutáveis da inteligência artificial fascinam e apavoram. Não sabemos se um dia a máquina sobrepujará o homem como o ser mais bem-sucedido. Todavia, uma realidade já não pode mais ser ignorada, as "máquinas invisíveis" (LUHMANN) transformaram a sociedade. Não sabemos ainda o real alcance da Quarta Revolução Industrial, mas seus efeitos se fazem sentir a cada dia com maior intensidade e, portanto, precisamos a ela nos adaptar e rapidamente.

A Era de Ouro do Direito do Trabalho (MANNRICH) provoca saudosismo. Há muitos nostálgicos que aguardam a volta dessa fase na qual havia crescentes conquistas sociais e pleno emprego. Refiro-me aí ao círculo virtuoso típico da fase do Fordismo, ou seja, quando o aumento progressivo de produtividade permitia crescimento da massa salarial, o que acarretava elevação do consumo e, por consequência, maior arrecadação. Isso, finalmente, possibilitava ampliação pelo Estado da proteção social (BOAVENTURA SANTOS). Esse panorama auspicioso, porém, começa a ruir a partir da década de 1960, com os avanços tecnológicos na produção industrial, as crises do petróleo da década de 1970 e a globalização. Hoje, em países com características de desenvolvimento semelhantes às do Brasil, aproximadamente metade dos trabalhadores estão relegados à informalidade, subemprego, desemprego ou mesmo ao desalento.

Nessas circunstâncias, o devir do Direito do Trabalho depende de sua reconhecida capacidade de evolução, sob pena de ser condenado à irrelevância e, assim, voltar a ser tratado como mero segmento do Direito Civil.

O Direito do Trabalho brasileiro precisa criar novos mecanismos para lidar com a realidade do trabalho sob demanda via aplicativos, que clama por reconhecimento. $\mathrm{O}$ antigo esquematismo binário de enquadramento da relação trabalhista - ou autônomo ou subordinado - provou-se superado. Noutros termos, ao se defender que a natureza jurídica do trabalho nesses moldes é autônoma exclui-se um contingente gigantesco de trabalhadores da proteção social básica conferida aos empregados registrados. Por outro lado, o reconhecimento do oneroso vínculo 
empregatício aí desestimula o recrutamento de milhões de trabalhadores, em sua grande maioria de baixa qualificação, que, ipso facto, dificilmente encontrariam oportunidade no mercado formal.

Por outras palavras, para se adaptar à progressiva complexidade do meio com as intensas transformações socioeconômicas e científico-tecnológicas da Revolução 4.0 o Direito do Trabalho necessita "evoluir". Não se trata aqui, porém, de resposta, ponto a ponto, a todos os estímulos oriundos de seu ambiente, o que implicaria autodestruição do microssistema jurídico trabalhista. Por sinal, evolução aí não deve ser deve ser compreendida como "progresso", mas de acordo com a semântica de NIKLAS LUHMANN, ou seja, como coevolução entre sistema e ambiente (CAMPILONGO, GONÇALVES e VILLAS BÔAS).

Vale dizer, evoluir não implica crescente proteção do empregado, atribuindose-lhe sempre mais e mais direitos, porém, com desprezo à situação de desemprego crônico que relega uma miríade de trabalhadores à revoltante condição de "ralé estrutural" (JESSÉ DE SOUZA). Cuida-se aqui, isto sim, da evolução concebida como capacidade de reagir aos estímulos externos de um meio hipercomplexo, porém, nos limites da autopoiese particular do microssistema jurídico trabalhista. Por outras palavras, para evoluir segundo sua própria autopoiese o Direito do Trabalho precisa aumentar sua complexidade interna (evolução endógena) e assim poder se autoadaptar diante dos desafios que o futuro contingente the reserva (evolução exógena).

Assim, sugerimos que a problemática imposta pela realidade do trabalho sob demanda via aplicativos quiçá possa ser enfrentada pela positivação do instituto da parassubordinação no Brasil. Aliás, cuida-se aí de figura naturalmente surgida da pressão de múltiplas forças antagônicas, quais sejam, a da autonomia e a da subordinação, mas dentro da unidade da relação de trabalho, consoante o princípio da unitas multiplex (HERÁCLITO). A propósito, de acordo com a semântica luhmanniana, frise-se, apenas com o aumento da própria complexidade do subsistema jurídico pode-se tentar reduzir a complexidade trazida a este último pela Quarta Revolução. 
Desse modo, teríamos, de uma banda, trabalhadores autônomos economicamente dependentes, ocupados e gozando ao menos de garantias sociais mínimas e, de outra banda, ambiente jurídico favorável aos investimentos. Estes últimos, por sua vez, capazes de gerar as tão ansiadas novas oportunidades de trabalho. Aliás, tudo consoante o princípio insculpido no art. 1ำ IV da Constituição de 1988, que declara serem fundamentos República Federativa do Brasil "os valores sociais do trabalho e da livre iniciativa".

Noutro giro, aqui não se defende ingenuamente que a solução de problemática dessa magnitude estaria na minuciosa regulamentação imperativa estatal. É certo que o Estado - enfraquecido em virtude da globalização - não tem condições de impor unilateralmente regras a serem observadas por todos (FARIA). O pluralismo jurídico, no entanto, indica que a ele cabe fazer ao menos a "pilotagem" do problema, por meio da criação de diretrizes que estabeleçam princípios e definições numa "moldura" ampla (ARNAUD).

Assim, semelhante arcabouço jurídico seria capaz de evitar conflitos desnecessários e ao mesmo tempo teria o condão de ser flexível o bastante para não se ver rapidamente obsoleto diante das vertiginosas transformações de nossa era. Cuida-se aqui de algo semelhante a um soft law, a estabelecer tão somente parâmetros abertos, deixando-se aos regulamentos de empresa, à autorregulação do mercado, aos contratos individuais e às convenções ou acordos coletivos de trabalho o detalhamento, bem como a atualização da matéria, agora, sim, com muito mais eficiência, rapidez, legitimidade e, por conseguinte, adesão das partes interessadas (TEUBNER). A propósito, a Carta de Bolonha de 2018 é para tanto uma bela inspiração.

Por outras palavras, o hipercomplexo panorama social contemporâneo não pode ser enxergado pelas lentes de um modelo anacrônico e saudosista. A propósito, a teoria dos sistemas luhmanniana pode aí ser manejada como instrumento para se pensar e sugerir tentativas de soluções no sentido da evolução do Direito do Trabalho. Aliás, disse LUHMANN que a teoria mencionada não promete final feliz, mas, em compensação, propõe aos que possuem fantasia, habilidade e curiosidade suficientes para se aventurar em seu labirinto, uma metáfora capaz de encarar a realidade da problemática trabalhista atual em toda sua dimensão. 
Por sinal, sustentamos que a relação de trabalho sob demanda via aplicativos — abstratamente encarada como "una" — trata-se de complexa trindade laica (unitas multiplex), cuja paradoxal natureza jurídica é variável de acordo com o entendimento de quem a observa e o método aplicado. Noutros termos, na seara acadêmica, defendemos que não se pode, a priori, estabelecer qual a natureza da nova modalidade de trabalho em questão, ou seja, se se trata de autônoma, subordinada ou parassubordinada. Todavia, reconhece-se que na prática forense semelhante tarefa é bastante facilitada por força da vedação do non liquet, imposta diante dos casos concretos. Porquanto no curso dos processos respectivos se pode estudar as alegações das partes, as provas produzidas nos autos e todas as circunstâncias ao derredor da matéria, inclusive, em último caso, lançando-se mão de presunções jurídicas para se construir um veredicto.

De qualquer sorte, ressalte-se que a dificuldade em se estabelecer a priori a natureza jurídica da relação de trabalho sob demanda via aplicativos não impede que se enfrente o problema da insegurança jurídica gerado pela falta da positivação heterônoma da matéria respectiva. Cuida-se aqui de proposta no sentido de que pelo menos os trabalhadores autônomos economicamente dependentes tenham direitos sociais mínimos garantidos. Nessa linha, competiria ao legislador apenas estabelecer um marco regulatório amplo, dentro da qual, por seu turno, caberia às próprias partes a regulação detalhada de assunto de seu imediato interesse. Isso modo muito mais dúctil, célere, legítimo e efetivo do que via processo legislativo.

Por outro lado, é importante ressaltar que a parassubordinação sugerida para enquadrar 0 trabalhador autônomo economicamente dependente demandado por aplicativos evidentemente aqui não é nem de longe encarada como panaceia. A hipercomplexidade da sociedade contemporânea, refletida mais precisamente nas relações de trabalho, não pode ser enfrentada apenas com a criação de uma terceira categoria de trabalhadores - a experiência italiana, frise-se, já o demonstrou. Todavia, ainda mais irrealista seria esperar nostalgicamente que voltássemos a experimentar o círculo virtuoso da Era Fordista. Aliás, é muito difícil antecipar os desdobramentos da Quarta Revolução Industrial que apenas desponta, porém, é certo que o pleno emprego se trata de espécie ameaçada de rápida extinção. Assim, se o 
Direito do Trabalho não se (auto)adaptar à evolução socioeconômica e tecnocientífica de nossa era tende a se desintegrar e ser reabsorvido pelo Direito Civil.

Fato é, contudo, que o trabalho humano sempre existirá. Embora empregos na indústria tendam a sofrer redução contínua, no setor de serviços há viés de crescimento, como na área do comércio, transportes e lazer, e.g., bem assim na de cuidados com idosos. Aliás, o subsistema jurídico, diante dos estímulos externos de outros sistemas sociais parciais presentes em seu ambiente, como os da Economia, Política e da Ciência - ainda que não responda ponto a ponto a estes últimos — se vê obrigado à (auto)evolução. Assim, o trabalho assalariado, embora continue a existir, aos poucos deve ir dando espaço ao autônomo ou parassubordinado.

Outra opção para enfrentar a problemática sub examine seria, e.g., a adoção, mutatis mutandis, do modelo trabalhista norte-americano, no qual os requisitos para configuração do vínculo empregatício são pouco rígidos, porém, o rol de direitos trabalhistas é bastante reduzido. Todavia, no curto e médio prazo, isso seria de dificilíssima implementação no Brasil. Tratar-se-ia de tour de force que acarretaria ainda mais insegurança, tendo vista contrariar sua tradição jurídica, ou seja, a História do Direito do Trabalho brasileiro. Por sinal, cada país deve encontrar a melhor abordagem do problema em foco de acordo com sua própria realidade, ordenamento e costumes. Porém, o que se espera do Direito do Trabalho pátrio é que não fique simplesmente inerte enquanto a sociedade evolui, sob pena de entrar em estado de entropia e desaparecer.

Aliás, a anomia presente vem dando azo ao ativismo judicial, o que deixa os interessados à mercê de uma miríade de decisões, muita vez conflitantes, em detrimento da segurança jurídica, necessária ao estímulo de investimentos e consequente geração de emprego e renda.

De outro lado, não podemos permanecer atônitos como o SANTO AGOSTINHO da fábula diante da criança que pretendia verter o mar num buraquinho. Socorremo-nos assim do princípio da unitas multiplex, de modo a se poder enxergar a unidade na diversidade e a diversidade na unidade (HERÁCLITO, AGOSTINHO, AQUINO e MORIN) para que possamos perceber a originalidade desta nova forma de relação de trabalho sob 
demanda via aplicativos - especificamente diferenciada pelo gerenciamento algorítmico com geolocalização. Aliás, não se pode ignorar o que este novo modelo pressagia como devir das relações trabalhistas. A propósito, é importante lembrar a lição heraclitiana de que o antagonismo presente na essência do uno provoca não apenas destruição, mas igualmente pode ser edificante.

Em síntese, concluímos sugerindo que a natureza jurídica da relação de trabalho sob demanda via aplicativos, "in abstracto", pode ser entendida como uma "unitas multiplex" (HeRÁClTO), cuja "unidade" - por paradoxal que pareça encontra-se numa "diferença", "forma" que a separa de outras relações (LUHMANN). A rigor, numa "diferença específica" (ARISTÓtELES), qual seja, o "gerenciamento algorítmico" da atividade respectiva pela plataforma, associado à "geolocalização" do profissional, considerando-se sua proximidade física do destinatário final do serviço. Isso a diferencia das relações de trabalho em geral, mais precisamente da estabelecida sob o sistema de crowdwork (STEFANO).

Por outras palavras, apenas nos casos concretos, com apoio do instrumental disponibilizado pelo subsistema jurídico pátrio, tal relação pode ser categorizada como autônoma ou subordinada. Todavia, ainda mais importante do que conseguirmos entender "se é isto ou aquilo" (MEIRELES) é mobilizarmo-nos para garantir a milhões de trabalhadores uma rede de proteção social básica, quiçá como parassubordinados (TRADEs digitais). Isso obviamente com a participação legitimante das partes interessadas, facilitada pelo Estado. Aliás, é essencial preservarem-se os benefícios socioeconômicos trazidos pela Revolução 4.0. Mas para tanto não podemos nos conformar com uma Constituição meramente simbólica (NEVES). Por sinal, lembre-se que um dos objetivos fundamentais da República é "construir uma sociedade livre, justa e solidária", que igualmente tem como um de seus fundamentos "a dignidade da pessoa humana". Em suma, o movimento pela garantia de direitos básicos aos trabalhadores em plataforma deve ter como inspiração os mencionados "valores sociais do trabalho e da livre iniciativa", esta díade, aliás, em aparente antagonismo, mas que, como perfeita tradução da "unitas multiplex", vem dando azo ao novo feitio do Direito do Trabalho. 


\section{REFERÊNCIAS}

ABBAGNANO, Nicola. Dicionário de filosofia. Tradução de Alfredo Bosi. São Paulo: Martins Fontes, 2000.

ADIGITAL. Propuesta normativa en materia de trabajo en plataformas digitales. Disponível em: <https://www.adigital.org/media/propuesta-regulatoria-plataformasdigitales.pdf>. Acesso em: 20 out. 2019.

AGOSTINHO, Santo. A Trindade. Tradução de Agustino Belmonte: São Paulo: Paulus, 1994.

ALMEIDA, Renato Rua de Almeida. Visão histórica da liberdade sindical. São Paulo: Revista LTr, 01 mar. 2006, p. 363-366. Disponível em:

$<$ http://www.renatoruaemarcusaquino.adv.br/publicacoes/renato_rua_visao_historica .pdf>. Acesso em: 5 out. 2019.

ALCOVERDE, Léo; PERRONI, Adriana. Roubos a motoristas de aplicativos crescem 18,5\% em São Paulo: no 10 trimestre deste ano, houve um salto de 839 para 995 casos em comparação ao mesmo período do ano anterior. GloboNews, 16 maio 2018. Disponível em: <https://g1.globo.com/sp/sao-paulo/noticia/roubos-amotoristas-de-aplicativos-crescem-185-em-sao-paulo.ghtml>. Acesso em: 02 maio 2019.

ALOISI, Antonio, STEFANO, Valerio De. II decreto riders fuori tempo massimo: un anno di attesa per consegnare un "pacco". Diritti comparati, 4 out. 2019. Disponível em: <http://www.diritticomparati.it/il-decreto-riders-fuori-tempo-massimo-un-anno-diattesa-per-consegnare-un-pacco/>. Acesso em: 11 out. 2019.

ALVARENGA, Darlan. País já tem 8,1 milhões de microempreendedores formais; veja atividades em alta entre MEls. G1, 3 abr. 2019. Disponível em: < https://g1.globo.com/economia/noticia/2019/04/03/pais-ja-tem-81-milhoes-demicroempreendedores-formais-veja-atividades-em-alta-entre-meis.ghtml>. Acesso em: 28 ago. 2019.

ALVES, Alaôr Caffé. Lógica: pensamento formal e argumentação. 4. ed. São Paulo: Quartier Latin, 2005.

ALVES, Amauri Cesar. Novo contrato de emprego: parassubordinação trabalhista. São Paulo: LTr, 2005. E-book.

AMARAL, Ana Maria Marcondes do. Dicionário jurídico italiano-português. São Paulo: Editora Federal, 2006

ANDRADE, Tatiana Guimarães Ferraz. Terceirização. Trabalho temporário. Trabalho autônomo. In: MANNRICH, Nelson. (Coord.). Reforma trabalhista: reflexões e críticas. São Paulo: LTr, 2018, p. 108-114. 
As novas faces da subordinação no contrato de trabalho. São Paulo, 2012, 180 f. Dissertação (Mestrado em Direito)-Universidade de São Paulo, São Paulo, 2012. Disponível em: <http://www.teses.usp.br/teses/disponiveis/2/2138/tde29102012-135506/en.php>. Acesso em: 10 abr. 2018.

AQUINO, Santo Tomás de. Suma Teológica. Tradução de Alexandre Correia. São Paulo: Odeon, 1936. Disponível em:

$<$ https://sumateologica.files.wordpress.com/2017/04/suma-teolc3b3gica.pdf>. Acesso em: 21 jun. 2019.

ARENDT, Hannah. A condição humana. Tradução de Roberto Raposo. 10. ed. Rio de Janeiro: Forense, 2009.

. Origens do totalitarismo. Tradução de Roberto Raposo. São Paulo: Companhia das Letras, 1989.

ARISTÓTELES. Tópicos. Edição: W. D. Ross. Elaboração: Centro de Filosofia da Universidade de Lisboa et al. Revisão: Levi Coutinho. Lisboa: Imprensa NacionalCasa da Moeda, 2007.

ARNAUD, André-Jean. Governar sem fronteiras: entre globalização e pósglobalização. Crítica da razão jurídica (vol. 2). Rio de Janeiro: Lumen Juris, 2007.

O Direito entre modernidade e globalização: lições de filosofia do Direito e do estado. Tradução de Patrice Charles Wuillaume. Rio de Janeiro: Renovar, 1999.

ARNAUD, André-Jean et al. Dicionário enciclopédico de teoria e de sociologia do Direito. Tradução de Patrice Charles e F.X. Willaume. Rio de Janeiro: Renovar, 1999.

BAPTISTA, Luiz Olavo. Aplicação do Direito estrangeiro pelo juiz brasileiro. Revista de Informação Legislativa. Brasília a. 36 n. 142 abr./jun. 1999, p. 267-278.

Disponível em: <http://www2.senado.leg.br/bdsf/bitstream/handle/id/490/r14221.PDF>. Acesso em: 1ํout. 2018.

BARASSI, Ludovico. Tratado de derecho del trabajo. Tomo I. Tradução de Miguel Sussini. Buenos Aires: Alfa, 1953.

BÁRCENAS, Francisco López. Ensayo sobre la ceguera... jurídica. Las teorías jurídicas y el derecho entre los ñuú savi. In CORREAS, Oscar. (Coord.). Pluralismo jurídico: otros horizontes. México, D.F.: Ediciones Coyocán, 2007, p. 67-120.

BARALDI, Claudio et al. Luhmann in glossario: I concetti fondamentali della teoria dei sistemi sociali. 4. ed. Milão: Franco Angeli, 2002.

. GLU: glosario sobre la teoría social de Niklas Luhmann. Tradução de Miguel Romero Pérez e Carlos Villalobos. México: Universidad Iberoamericana, 1996.

BARROS, Alice Monteiro de. Curso de direito do trabalho. 5. ed. São Paulo: LTr, 2009. 
—. Curso de Direito do trabalho. São Paulo: LTr, 2005.

BARROS, Alisson Victor Rodrigues. Personalidade jurídica e responsabilidade civil do microempreendedor individual. Revista Jurídica do Banco do Nordeste. Vol. 01, no 4, jul-dez 2016, p. 228-258. Disponível em:

<https://www.bnb.gov.br/documents/50268/204420/PERSONALIDADE_JURIDICA_E RESPONSABILIDADE_CIVIL_DO_MICROEMPREENDEDOR_INDIVIDUAL/4396̄b 73b-4c9b-f9c2-3871-76e66f404ce0 $>$. Acesso em: 28 ago. 2019.

BARROS, Carlos Juliano. Algoritmos das redes sociais promovem preconceito e desigualdade, diz matemática de Harvard. BBC Brasil, 24 dez. 2017. Disponível em: <http://www.bbc.com/portuguese/geral-4239833>. Acesso em: 21 jan. 2018.

BATALHA, Wilson de Souza Campos. Tratado de direito judiciário do trabalho. 2. ed. São Paulo: LTr, 1985.

. Introdução ao direito. V. II. São Paulo: Revista dos Tribunais, 1968.

BAUMAN, Zygmunt. Modernidade líquida. Tradução de Plínio Dentzien. Rio de Janeiro: Zahar, 2001.

BAUMAN, Zygmunt; TESTER, Keith. Bauman sobre Bauman: diálogos com Keith Tester. Tradução de Carlos Alberto Medeiros. Rio de Janeiro: Zahar, 2011.

BBC Brasil. Bitcoin: o que é e como funciona a moeda virtual, 11 dez. 2017. Disponível em: <https://www.bbc.com/portuguese/brasil-42313567>. Acesso em: 26 out. 2018.

Os motivos que levaram o fundador do Uber a cair em desgraça - e deixar o comando da empresa, 14 jun. 2017. Disponível em:

<http://www.bbc.com/portuguese/geral-40275153>. Acesso em: 18 jan. 2018.

CHAVES JÚNIOR, José Eduardo de Resende; MENDES, Marcus Menezes Barberino; OLIVEIRA, Murilo Carvalho Sampaio. Subordinação, dependência e alienidade no trânsito para o capitalismo tecnológico. In LEME, Ana Carolina Reis Paes et al. (Coords.). Tecnologias disruptivas e a exploração do trabalho humano. São Paulo: LTr, 2017, p. 166-179. E-book.

BELLAN, Marie; COMARMOND, Leïla de. Travailleurs des plates-formes: le gouvernement cherche. Les Echos, 21 maio 2019. Disponível em:

$<$ https://www.lesechos.fr/economie-france/social/travailleurs-des-plates-formes-legouvernement-cherche-une-issue-1022927>. Acesso em: 21 out. 2019.

BERG, Janine et al. Digital labour platforms and the future of work: towards decent work in the online world. Genebra: ILO, 2018. Disponível em:

$<$ https://www.ilo.org/wcmsp5/groups/public/---dgreports/---dcomm/---

publ/documents/publication/wcms_645337.pdf>. Acesso em: 02 maio 2019.

BERTALANFFY, Ludwig von. Teoría general de los sistemas: fundamentos, 
desarrollo, aplicaciones. Tradução de Juan Almela. México, D.F.: Fondo de Cultura Económica, 1976.

BERTAGNOLLI, Danielle; RIZZOTO, Felipe; TONIAL, Maira Angélica Dal Conte. As relações de trabalho e a automação industrial: reflexões sobre os aspectos históricos, econômicos, conceituais e sociais. Revista justiça do Direito, v. 24, n. 1, 2010, p. 132-150. Disponível em: < http://seer.upf.br/index.php/rjd/article/view/2149/1389>. Acesso em: 4 mar. 2019.

BESSA, Cesar. Além da subordinação jurídica no direito do trabalho. São Paulo: LTr, 2017. E-book.

BOBBIO, Norberto. Teoria geral do direito. Tradução de Denise Agostinetti e revisão da tradução de Silvana Cobucci Leite. 3. ed. São Paulo: Martins Fontes, 2010.

Da estrutura à função: novos estudos de teoric
Daniela Beccaccia Versiani. Barueri: Manole, 2007.

BOBBIO, Norberto et al. Dicionário de política. Tradução de Carmen C. Varriale et al. Brasília: Editora Universidade de Brasília, 1998.

BONAVIDES, Paulo. Curso de direito constitucional. 17. ed. São Paulo: Malheiros, 2005.

BORBA, Joselita Nepomuceno. Configuração jurídica da subordinação e sua importância na requalificação do contrato. Trabalho subordinado e trabalho autônomo. In FREDIANI, Yone. (Coord.). A valorização do trabalho autônomo e a livre-iniciativa. Porto Alegre: Magister, 2015, p. 109-130.

BORGES, Jorge Luis; GUERRERO, Margarita. El libro de los seres imaginários. Buenos Aires: Kier, 1967, p. 53 e 55-56. Disponível em:

<biblio3.url.edu.gt/Libros/borges/imaginarios.pdf>. Acesso em: 19 jan. 2018.

BORGES, Thais. Até 14 horas de trabalho e $80 \mathrm{~km}$ pedalados por dia: conheça os entregadores por aplicativo, Correio, 30 jun. 2019. Disponível em: <

https://www.correio24horas.com.br/noticia/nid/ate-14-horas-de-trabalho-e-80-kmpedalados-por-dia-conheca-os-entregadores-por-aplicativo/>. Acesso em: 11 out. 2019.

BOUDON, Raymond; BOURRICAUD, François. Dicionário crítico de sociologia. Tradução de Maria Letícia Guedes Alcoforado e Durval Ártico. São Paulo: Ática, 1993.

BRASIL. Câmara dos Deputados. Parecer do relator ao PL 6787/2016, 12 abr. 2017. Disponível em:

<http://www.camara.gov.br/proposicoesWeb/prop_mostrarintegra?codteor $=1544961$ \&filename=PRL+1+PL678716+\%3D\%3E+PL+6787/2016>. Acesso em: 7 set. 2018.

BRASIL. IPEA. Petróleo: da crise aos carros flex. Desafios do desenvolvimento. Ano 7. Edição 59, 29 mar. 2010. Disponível em: < 
http://www.ipea.gov.br/desafios/index.php?option=com_content\&view=article\&id=232 1 : catid=28\&ltemid=23 > . Acesso em: 13 fev. 2018.

BRASIL. Ministério da Fazenda. Secretaria de Previdência. BA: Aposentadorias são 57\% dos benefícios pagos na Bahia, 29 abr. 2015. Disponível em: <http://www.previdencia.gov.br/2015/04/ba-aposentadorias-sao-57-dos-beneficiospagos-na-bahia/>. Acesso em: 16 maio 2018.

BRASIL. Ministério do Trabalho. OLIVEIRA, Ronaldo Nogueira de. Exposição de motivos $n^{\circ}$ 00023/2017 MTB. Brasília, 9 nov. 2017. Disponível em:

<http://www.planalto.gov.br/ccivil_03/_Ato2015-2018/2017/Exm/Exm-MP-808-

17.pdf>. Acesso em: 5 set. 2018.

BRASIL. Portal do Empreendedor-MEl. Dúvidas mais frequentes sobre microemprendedor individual. Disponível em:

$<$ https://www.portaldoempreendedor.gov.br/duvidas-mais-sobre-o-mei/as-duvidasmais-frequentes-sobre-o-microemprendedor-individual/2-como-eu-faco-para-abrirum-microempreendedor-individual-mei>. Acesso em: 17 ago. 2019.

BRASIL. Senado Federal. Subcomissão apresenta primeira versão do estatuto do trabalho. 10 maio 2018. Disponível em:

$<$ https://www12.senado.leg.br/noticias/materias/2018/05/10/subcomissao-apresentaprimeira-versao-do-estatuto-do-trabalho>. Acesso em: 5 set. 2018.

BRASIL Sistema de normas gestão da informação. Disponível em:

$<$ http://normas.receita.fazenda.gov.br/sijut2consulta/link.action?idAto=92278\&visao= anotado>. Acesso em: 17 ago. 2019.

BRESSER-PEREIRA, Luiz Carlos. Afinal, a estagnação secular do capitalismo? Revista Brasileira de Ciências Sociais, vol. 33, n 96, São Paulo, 2018. Disponível em: < http://www.bresserpereira.org.br/works/prefacesreviews/2018/R63-GordonRBCS.pdf>. Acesso em: 12 jul. 2018.

BRITO FILHO, José Cláudio Monteiro de. Direito sindical. 3. ed. São Paulo: LTr, 2009.

BUBOLA, Gabriele; VENTURI, Davide. La parasubordinazione non eteroorganizzata dopo il Jobs Act. Working Paper ADAPT, 21 dez. 2015, n. 187. Disponível em:

<https://moodle.adaptland.it/pluginfile.php/22376/mod_resource/content/16/wp_2015 187.pdf>. Acesso em: 16 maio 2018.

BUCHANAN, Robert Angus. History of technology. Encyclopædia Britannica, 5 jan. 2008. Disponível em: <https://www.britannica.com/technology/history-oftechnology $>$. Acesso em: 5 set. 2018.

BUCHANAM, Ruth. Reconceptualización del derecho y la política em lo transnacional: acercamientos pluralistas constitucionales y jurídicos. In CORREAS, Oscar. (Coord.). Pluralismo jurídico: otros horizontes. México, D.F.: Ediciones Coyocán, 2007, p. 225-248. 
BULGUERONI, Renata Orsi. Trabalho autônomo dependente: experiências italiana e espanhola e realidade brasileira. 2011, 244 f. Dissertação (Mestrado em Direito)Universidade de São Paulo, São Paulo, 2011. Disponível em:

<http://www.teses.usp.br/teses/disponiveis/2/2138/tde-18052012-135740/pt-br.php>. Acesso em: 10 abr. 2018.

BURNS, Edward McNall. História da civilização ocidental. Vol. I. Tradução de Lourival Gomes Machado et al. 25. ed. Porto Alegre-Rio de Janeiro: Globo, 1983.

CUÉLLAR, Nelcy López. Pluralismo jurídico estatal: entre conflito y diálogo. Tradução de Pedro Javier López Cuéllar. Bogotá: Editorial Universidad del Rosario, 2015.

CADAMINUTO. MPF investiga Uber por exploração de motoristas em São Paulo. Disponível em: <https://www.cadaminuto.com.br/noticia/308239/2017/08/11/mpfinvestiga-uber-por-exploracao-de-motoristas-em-sao-paulo>. Acesso em: 16 maio 2019.

CALDAS, Aulete et al. Dicionário Aulete digital. Disponível em: <http://www.aulete.com.br>. Acesso em: 5 set. 2018.

CAMPILONGO, Celso Fernandes. Política, sistema jurídico e decisão judicial. 2. ed. São Paulo: Saraiva, 2011.

Interpretação do direito e movimentos sociais. Rio de Janeiro: Elsevier Brasil, 2011.

—. O direito na sociedade complexa. São Paulo: Max Limonad, 2000.

CAMPOS, ELISA et. al. Como a computação quântica vai abalar os negócios para sempre: A tecnologia dá os primeiros passos fora dos laboratórios para entrar no dia a dia das empresas. Época negócios, 08 fev. 2019. Disponível em:

<https://epocanegocios.globo.com/Tecnologia/noticia/2019/02/como-computacaoquantica-vai-abalar-os-negocios-para-sempre.html>. Acesso em: 30 jul. 2019.

CANALTECH. Uber é condenada a pagar US\$ 8,9 mi por aceitar motoristas com ficha criminal. 21 nov. 2017. Disponível em: <https://canaltech.com.br/juridico/uber-econdenada-a-pagar-us-89-mi-por-aceitar-motoristas-com-ficha-criminal-103924>. Acesso em: 18 jan. 2018.

CANCIAN, Natália; LADEIRA, Pedro. Mantido ritmo, Brasil vai atrasar em 30 anos meta de saneamento universal: no país, 100 milhões vivem sem acesso à rede de esgoto; falta de planejamento e investimento agrava quadro. Folha de São Paulo, 9 out. 2019. Disponível em: <https://www1.folha.uol.com.br/cotidiano/2019/10/mantidoritmo-brasil-vai-atrasar-em-30-anos-meta-de-saneamento-universal.shtml>. Acesso em: 10 out. 2019.

CANOTILHO, José Joaquim Gomes. Parecer. 4 nov. 2015. Disponível em < https://www.conjur.com.br/dl/parecer-canotilho-uber.pdf>. Acesso em: 14 out 2019. 
2003.

CANOTILHO, José Joaquim Gomes; MOREIRA, Vital. Constituição da república portuguesa anotada. V. I. São Paulo: Revista dos Tribunais e Coimbra Editora, 2007.

CAPPONI, Federica; PELUSI, Lorenzo Maria. Le nuove tutele del lavoro tramite piattaforma "anche" digitale: commento al d.I. n. 101/2019. Bollettino ADAPT, № 31, 9 set. 2019. Disponível em: <http://www.bollettinoadapt.it/le-nuove-tutele-del-lavorotramite-piattaforma-anche-digitale-commento-al-d-I-n-101-2019/>. Acesso em: 11 out. 2019.

CAPRA, Fritjof. A teia da vida: uma nova compreensão dos sistemas vivos. Tradução de Newton Roberval Eichemberg. São Paulo: Cultrix, 2006.

CARINCI, Franco et. al. Diritto del lavoro, vol. 2. II rapporto di lavoro subordinato. 6 . ed. Torino: UTET, 2005.

CARNEIRO, Luiz Orlando. STF tem votos para unificar entendimento sobre Uber: Roberto Barroso, Alexandre de Moraes, Marco Aurélio e Dias Toffoli reconheceram repercussão geral. Jota. 3 dez. 2017. Disponível em:

$<$ https://www.jota.info/justica/stf-tem-votos-para-unificar-entendimento-sobre-uber03102017>. Acesso em: 15 jan. 2018.

CARVALHO, Augusto César Leite de. Direito do trabalho: curso e discurso. 3. ed. São Paulo: LTr, 2019. E-book.

CASSAR, Vólia Bomfim. Uma das novidades da reforma trabalhista: o contrato intermitente. In A reforma trabalhista: na visão da Academia Brasileira de Direito do Trabalho. Porto Alegre: Lex magister, 2018, p. 186-190.

- Reforma trabalhista: comentários ao substitutivo do projeto de lei 6787/16. Migalhas, 3 maio 2017. Disponível em: $<$ https://www.migalhas.com.br/dePeso/16,MI258190,41046-

Reforma+trabalhista+Comentarios+ao+substitutivo+do+projeto+de+lei>. Acesso em: 5 set. 2018.

CASTIEL, Luis David. Metáforas para uma epidemiologia mestiça. In ALMEIDA FILHO, Naomar et al. (Orgs.). Teoria epidemiológica hoje: fundamentos, interfaces, tendências. Rio de Janeiro: FIOCRUZ, 1998, p. 227. Disponível em: <http://books.scielo.org/id/5btwk/pdf/almeida-9788575412794.pdf>. Acesso em: 14 ago. 2019.

CAVALCANTE, Jouberto de Quadros Pessoa. Sociedade, tecnologia e a luta pelo emprego. São Paulo: LTr, 2018. E-book.

CESARINO JÚNIOR, Antônio Ferreira. Direito social. São Paulo: LTr-USP, 1980. 
CHAUI, Marilena. Introdução à história da filosofia: dos pré-socráticos a Aristóteles, volume 1. 2. ed. São Paulo: Companhia das Letras, 2002.

CONSULTOR JURÍDICO. Europa passa a considerar Uber um serviço de transporte, 20 dez. 2017. Disponível em: <https://www.conjur.com.br/2017-dez-20/europapassa-considerar-uber-servico-transporte?imprimir=1>. Acesso em: 8 jan. 2018.

CORREAS, Oscar. (Coord.). Pluralismo jurídico: otros horizontes. México, D.F.: Ediciones Coyocán, 2007.

CORREIO24 HORAS. Salvador ganha aplicativo de mobilidade 100\% baiano: desenvolvido no Parque Tecnológico da Bahia, itMOV oferece serviço pautado em qualidade, segurança e inovação tecnológica, 16 ago. 2018, Estúdio Correio. Disponível em: <https://www.correio24horas.com.br/noticia/nid/salvador-ganhaaplicativo-de-mobilidade-100-baiano/>. Acesso em: 04 maio 2019.

CUEVA, Mario de la. El nuevo derecho mexicano del trabajo. T. I. 18. ed. Cidade do México: Porrúa, 2001.

CUNHA, Marisa Ortegoza da. Sobre a ideia de algoritmo. In: SEMINÁRIOS DE ESTUDOS EM EPISTEMOLOGIA E DIDÁTICA (SEED-FEUSP), 2007, São Paulo. Disponível em: <https://www.nilsonjosemachado.net/20070601.pdf>. Acesso em: 27 set. 2019.

CRUZ, Elaine Patricia. Mais de 1,5 mil motoristas de aplicativos já são microempreendedores: com MEI, profissional tem cobertura previdenciária e emite nota fiscal. Agência Brasil, 30 ago. 2019. Disponível em: <http://agenciabrasil.ebc.com.br/economia/noticia/2019-08/mais-de-15-milmotoristas-de-aplicativos-ja-se-registraram-como-meivv>. Acesso em: 27 out. 2019.

DAVID, René; JAUFFRET-SPINOSI, Camille. Los grandes sistemas jurídicos contemporáneos. Tradução de Jorge Sánchez Cordero. 11. ed. Cidade do México: Universidad Nacional Autónoma de México, 2010.

DE GIORGI, Raffaele de. Luhmann e a teoria jurídica dos anos 70, em apêndice à obra de CAMPILONGO, Celso Fernandes. O Direito na sociedade complexa. São Paulo: Max Limonad, 2000.

DE STEFANO, Valerio. "Negotiating the algorithm": automation, artificial intelligence and labour protection. ILO, Employment working paper $n^{\circ}$ 246, 2018. Disponível em: $<$ https://www.ilo.org/wcmsp5/groups/public/---ed_emp/--emp_policy/documents/publication/wcms_634157.pdf>. Acesso em: 28 mar. 2019.

- The rise of the "just-in-time workforce": on-demand work, crowdwork and labour protection in the "gig-economy". ILO, Conditions of work and employment series $n^{\circ}$ 71, 2016. Disponível em: <http://www.ilo.org/wcmsp5/groups/public/--ed_protect/---protrav/---travail/documents/publication/wcms_443267.pdf>. Acesso em: 29 abr. 2017. 
DELGADO, Maurício Godinho. Direitos fundamentais na relação de trabalho. Revista de Direitos e garantias fundamentais, № 2, 2007. Disponível em: < http://sisbib.fdv.br/index.php/Direitosegarantias/article/view/40/38>. Acesso em: 11 set. 2017.

DELGADO, Mauricio Godinho. Curso de direito do trabalho. 17. ed. São Paulo: LTr, 2018.

—. Curso de direito do trabalho. 8. ed. São Paulo: LTr, 2009.

DIAS, Carlos. Vale a pena ser motorista do Uber? Para os motoristas que trabalham com o aplicativo, onda de bons rendimentos se foi e ganho é pequeno hoje. Istoé Dinheiro, 2 dez. 2016. Disponível em:

<https://www.istoedinheiro.com.br/noticias/economia/20160711/vale-pena-sermotorista-uber/392033>. Acesso em: 18 maio 2019.

DINIZ, Maria Helena. Curso de Direito civil brasileiro: Direito de empresa. Vol. 8. 9. ed. São Paulo: Saraiva, 2017.

—. Código Civil anotado. 15. ed. São Paulo: Saraiva, 2010.

Curso de Direito civil brasileiro: teoria geral do Direito civil. Vol. 1. 22. ed. São Paulo: Saraiva, 2005.

DURKHEIM, Émile. Da divisão do trabalho social. 2. ed. Tradução de Eduardo Brandão. São Paulo: Martins Fontes, 1999.

DWORKIN, Ronald. Levando os Direitos a sério. Tradução de Nelson Boeira. São Paulo: Martins Fontes, 2002.

EBERT, Paulo Roberto Lemgruber. O trabalho autônomo na reforma trabalhista da fórmula política da Constituição Federal de 1988. In ANAMATRA. Revista trabalhista: Direito e processo, ano 16, no 58, 2018, São Paulo: LTr, 2018. E-book.

EHRLICH, Eugen. Fundamentos da sociologia do Direito. Tradução de René Ernani Gertz. Brasília: Editora UnB, 1986.

EINSTEIN: vida e pensamentos. São Paulo: Martin Claret, 2002.

CORTÉS, Raquel Pascual. ATA pide que se cree el 'autónomo dependiente digital' con una retribución mínima de 1.050 euros. El País, 24 mar. 2019. Disponível em: <https://cincodias.elpais.com/cincodias/2019/03/14/midinero/1552577219_250247.ht ml>. Acesso em: 20 out. 2019.

ENCYCLOPAEDIA BRITANNICA. St. Thomas Aquinas, 3 mar. 2019. Disponível em: $<$ https://www.britannica.com/biography/Saint-Thomas-Aquinas >. Acesso em: 28 mar. 2019. 
- Thirty years' war. 20 set. 2018. Disponível em:

<https://www.britannica.com/event/Thirty-Years-War>. Acesso em: 22 out. 2018.

. The unicorn start-up phenomenon. 11 ago. 2016. Disponível em:

$<$ https://www.britannica.com/editor/The-Editors-of-Encyclopdia-Britannica/4419>. Acesso em: 13 jan. 2018.

—. Heraclitus, 26 jan. 2015. Disponível em:

<https://www.britannica.com/biography/Heraclitus>. Acesso em: 28 mar. 2019.

ESTEVES, Alan da Silva. Proteção do trabalhador em face da automação: eficácia jurídica e social do inciso XXVII do art. $7^{\circ}$ da constituição brasileira. São Paulo: LTr, 2013. E-book.

FARIA, José Eduardo. O estado e o Direito depois da crise. 2. ed. São Paulo: Saraiva, 2017.

- (Org.). Direito e globalização econômica: implicações e perspectivas. São Paulo: Malheiros, 2015.

. Democracia e governabilidade: os Direitos humanos à luz da globalização econômica. In FARIA, José Eduardo. (Org.). Direito e globalização econômica: implicações e perspectivas. São Paulo: Malheiros, 2015, p. 127-160.

Direito e conjuntura. 2. ed. São Paulo: Saraiva, 2010.

FARIA, José Eduardo; KUNTZ, Rolf. Qual o futuro dos direitos? Estado, mercado e justiça na reestruturação capitalista. São Paulo: Max Limonad, 2002.

FAUSTO, Boris. História do Brasil. 14. ed. Colaboração de Sergio Fausto. São Paulo: Edusp, 2015.

FEIGELSON, Bruno et al. Aplicativos de transporte: riscos do novo marco regulatório: renasce, no horizonte constitucional, o temor da insegurança jurídica e do desamparo institucional. Jota, 22 abr. 2018. Disponível em:

<https://www.jota.info/opiniao-e-analise/artigos/aplicativos-de-transporte-riscos-donovo-marco-regulatorio-22042018>. Acesso em: 12 jul. 2018.

FERRAZ JUNIOR, Tercio Sampaio. Introdução ao estudo do Direito. 4. ed. São Paulo: Atlas, 2003.

FERREIRA, Aurélio Buarque de Holanda. Novo dicionário da língua portuguesa. 2. ed. Rio de Janeiro, 1986.

FERREIRA, Franklin. Agostinho e a Santíssima Trindade. Voltemos ao Evangelho, 25 abr. 2018. Disponível em:

<https://voltemosaoevangelho.com/blog/2018/04/agostinho-e-a-santissima-

trindade/>. Acesso em: 17 jun. 2019. 
FIGUEIREDO, Guilherme José Purvin de. Direito ambiental e a saúde dos trabalhadores. 4. ed. São Paulo: LTr, 2007.

FLORIAN, Eugenio. De las pruebas penales. V. II. Bogotá: Temis, 1969.

FOLHA DE SÃO PAULO. Juíza autoriza concessão de nova licença de operação à Uber em Londres: licença foi suspensa em 2017; empresa ganhou autorização para operar por 15 meses, 27 jun. 2018. Disponível em:

<https://www1.folha.uol.com.br/mercado/2018/06/juiza-autoriza-concessao-de-novalicenca-de-operacao-a-uber-em-londres.shtml>. Acesso em: 27 jun. 2018.

Carro autônomo da Uber nos EUA causa primeira morte por atropelamento: empresa suspendeu testes com veículos sem motorista nos Estados Unidos e no Canadá, 19 mar. 2018. Disponível em:

<https://www1.folha.uol.com.br/mercado/2018/03/mulher-morre-nos-eua-apos-seratropelada-por-carro-autonomo-da-uber.shtml>. Acesso em: 20 mar. 2018.

Informalidade se consolida como motor da recuperação do emprego: os sem carteira somam 34,2 milhões, número acima dos que usufruem da CLT, 1 fev. 2018. Disponível em: <https://www1 folha.uol.com.br/mercado/2018/02/1954907informalidade-se-consolida-como-motor-da-recuperacao-do-emprego.shtml>. Acesso em: 6 fev. 2018.

\section{Online, 3 fev. 2009. Disponível em:}

<https://m.folha.uol.com.br/mercado/2009/02/498060-entenda-a-evolucao-da-criseque-atinge-a-economia-dos-eua.shtml>. Acesso em: 11 mai. 2009.

FRAGA, Érica. Não dar seguro saúde e Previdência a terceirizado é escândalo, diz José Pastore: Governos e mercado devem criar produtos de proteção para trabalho flexível, diz sociólogo. Folha de São Paulo, 19 ago. 2019. Disponível em:

<https://www1.folha.uol.com.br/mercado/2019/08/nao-dar-seguro-saude-eprevidencia-a-terceirizado-e-escandalo-diz-jose-pastore.shtml>. Acesso em: 19 ago. 2019.

FRANCO FILHO, Georgenor de Sousa. Curso de Direito do trabalho. 5. ed. São Paulo: LTr, 2019. E-book.

FRANÇA. IGF. CHARPIN, Jean-Michel et al. Ouverture de l'assurance chômage aux travailleurs indépendants, out. 2017. Disponível em:

<http://www.igf.finances.gouv.fr/files/live/sites/igf/files/contributed/IGF\%20internet/2. RapportsPublics/2017/2017-M-048.pdf>. Acesso em: 2 jun. 2018.

FREITAS, Eduardo de. Primeira Revolução Industrial. Brasil escola. Disponível em <http://brasilescola.uol.com.br/geografia/primeira-revolucao-industrial.htm>. Acesso em 12 de fevereiro de 2018.

FREITAS JÚNIOR, Antonio Rodrigues de. Direitos sociais e Direitos fundamentais na perspectiva da declaração da OIT de 1998: um caso de soft law no rumo de sua efetividade. In GOMES, Ana Virgínia Moreira; FREITAS JÚNIOR, Antonio Rodrigues 
de. (Orgs.). A declaração de 1998 da OIT sobre princípios e Direitos fundamentais no trabalho: análise do seu significado e efeitos. São Paulo: LTr, 2014, p. 13-18. Ebook.

FRIEDMAN, Milton. Capitalismo e liberdade. Tradução de Afonso Celso da Cunha Serra. Rio de Janeiro: LTC, 2017.

GAGLIANO, Pablo Stolze; PAMPLONA FILHO, Rodolfo. Manual de direito civil. São Paulo: Saraiva, 2017.

GAVRAS, Douglas. 5,5 milhões usam apps de transporte para trabalhar: Desemprego e popularização do serviço impulsionam trabalho com as plataformas, mas relação de motoristas com aplicativos é sensível. O Estado de S. Paulo, 28 abr. 2019. Disponível em: <https://economia.estadao.com.br/noticias/geral,5-5-milhoesusam-apps-de-transporte-para-trabalhar,70002807114>. Acesso em: 01 maio 2019.

Aplicativos como Uber e iFood são fonte de renda de quase 4 milhões de autônomos: com retomada lenta da economia e mercado de trabalho sem reação, apps de serviço se tornaram, em conjunto, o maior 'empregador' do País. O Estado de S. Paulo, 28 abr. 2019. Disponível em:

$<$ https://economia.estadao.com.br/noticias/geral,aplicativos-como-uber-e-ifood-saofonte-de-renda-de-quase-4-milhoes-de-autonomos,70002807079>. Acesso em: 26 maio 2019.

GAZETA DO POVO. Acordo trabalhista de US\$100 milhões com Uber é rejeitado nos EUA: se os quase 385 mil motoristas e ex-motoristas que movem a ação forem classificados como funcionários da empresa, todo o modelo de operação do aplicativo estará em risco. The Washington Post, com tradução e colaboração de Fabiane Ziolla Menezes, 24 ago. 2016. Disponível em: <http://www.gazetadopovo.com.br/vida-e-cidadania/futuro-das-cidades/acordotrabalhista-de-us-100-milhoes-com-uber-e-rejeitado-nos-eua8pa0lnv53dtlyud22q3tmmec8>. Acesso em: 15 jan. 2018.

GETNINJAS. Termos e condições gerais de uso do site, 17 jun. 2019. Disponível em: <https://www.getninjas.com.br/termos-de-uso>. Acesso em: 17 jun. 2019.

Sobre o GetNinjas, 19 jan. 2018. Disponível em:

<https://www.getninjas.com.br/quem-somos>. Acesso em: 19 jan. 2018.

GOFF, Jacques Le. A civilização do ocidente medieval. Tradução de Monica Stahel. Petrópolis: Vozes, 2016.

GOMES, Ana Virgínia Moreira. Desafios para a regulação: profissionais liberais, categorias profissionais diferenciadas e os Ipros. In: CONGRESSO INTERNACIONAL DE DIREITO DO TRABALHO, 4., 2014, São Paulo. Anais [...]. In MANNRICH, Nelson et al. (Coords.). Reinvenção do direito do trabalho: crise econômica e desajustes sociais: Anais da Academia Brasileira de Direito do Trabalho 2014. Porto Alegre: Magister, 2015, p. 235-244. 
GOMES, Helton Simões. Motorista da Uber nos EUA ganha pouco e fica abaixo da linha da pobreza. UOL, 8 out. 2018. Disponível em: < https://noticias.uol.com.br/tecnologia/noticias/redacao/2018/10/08/motorista-do-ubernos-eua-ganha-pouco-e-fica-abaixo-da-linha-da-pobreza.htm>. Acesso em: 27 maio 2019.

GOMES, Orlando. Contratos. 12. ed. Rio de Janeiro: Forense, 1990.

- O destino do Direito do trabalho. Revista da Faculdade de Direito UFPR. V. 5,1957. Disponível em: <https://revistas.ufpr.br/Direito/article/download/6601/4720>. Acesso em: 22 out. 2018.

GOMES, Orlando; GOTTSCHALK, Elson. Curso de direito do trabalho. 17. ed. Atualização de José Augusto Rodrigues Pinto e Otávio Augusto Reis de Souza. Rio de Janeiro: Forense, 2005.

Curso de direito do trabalho. 11. ed. Rio de Janeiro: Forense, 1990.

GÓMEZ, Manuel V.; DELGADO, Cristina. La Seguridad Social gana el macrojuicio contra Deliveroo: los 'riders' son asalariados, no autónomos. El Juzgado de lo Social número 19 de Madrid da la razón a la Inspección de Trabajo, que obligó a dar de alta a los repartidores. El País, 23 jul. 2019. Disponível em:

<https://elpais.com/economia/2019/07/23/actualidad/1563869784_655574.html>. Acesso em: 31 ago. 2019.

GOULART, Rodrigo Fortunato; VILLATORE, Marco Antônio César. Proteção ao trabalhador economicamente dependente: propostas para um novo contrato de trabalho. In: CONGRESSO NACIONAL DO CONPEDI, XVII, 2008, Brasília, 2008. Anais [...]. Disponível em:

<http://www.publicaDireito.com.br/conpedi/manaus/arquivos/anais/brasilia/10_188.pd f>. Acesso em: 10 abr. 2018.

GONÇALVES, Guilherme Leite. Direito entre certeza e incerteza: horizontes críticos para a teoria dos sistemas. São Paulo: Saraiva, 2013.

GONÇALVES, Guilherme Leite; Villas Bôas Filho, Orlando. Teoria dos sistemas sociais: Direito e sociedade na obra de Niklas Luhmann. São Paulo: Saraiva, 2013.

GRAGNANI, Juliana. Motoristas 'exaustos' do aplicativo Uber assustam passageiros em SP. Folha de São Paulo, 18 set. 2016. Disponível em:

<https://m.folha.uol.com.br/cotidiano/2016/09/1814456-motoristas-exaustos-doaplicativo-uber-assustam-passageiros-em-sp.shtml>. Acesso em: 18 maio 2019.

GRIMES, Katy. California ride-share gig companies facing takeover by Labor Unions 300,000 Lyft drivers will be out of work if there is no fix to Dynamex or AB 5.

California Globe, 30 ago. 2019. Disponível em: <https://californiaglobe.com/section2/california-ride-share-gig-companies-facing-takeover-by-labor-unions/>. Acesso em: 31 ago. 2019. 
GRINOVER, Ada Pellegrini et al. Código brasileiro de defesa do consumidor. 4. ed. Rio de Janeiro: Forense, 1995.

GROEN, Willem Pieter de et al. Employment and working conditions of selected types of platform work. Luxemburgo: Eurofound, 2018. Disponível em:

<https://www.eurofound.europa.eu/sites/default/files/ef_publication/field_ef_documen t/ef18001en.pdf>. Acesso em: 14 out. 2019.

GUERRA FILHO, Willis Santiago. Teoria da ciência jurídica. 2. ed. São Paulo: Saraiva, 2009.

\section{Introdução à filosofia. Manuscrito do autor, São Paulo, 2009, 274 f.}

GINÉS, Guillermo. Las plataformas digitales piden que la ley reconozca a los «riders» como autónomos: Glovo, Uber Eats, Deliveroo y Stuart aseguran que estos repartidores tienen unos ingresos medios de entre 8 y 11 euros por hora. $A B C, 16$ jul. 2019. Disponível em: <https://www.abc.es/economia/abci-plataformas-digitalespiden-ley-reconozca-riders-como-autonomos-201907161316_noticia.html>. Acesso em: 20 out. 2019.

GUNKEL, David J. Comunicação e inteligência artificial: novos desafios e oportunidades para a pesquisa em comunicação. Tradução de Francisco B. Trento e Daniela Norcia Gonçalves. São Paulo: Galaxia, n. 34, jan-abr. 2017, p. 05-19. Disponível em: <http://www.scielo.br/scielo.php?script=sci_arttext\&pid=S1982$25532017000100005 \&$ Ing=en\&nrm=iso\&tlng=pt>. Acesso em: 28 set. 2019.

GUREVICH, Yuri. What is an algorithm? Microsoft Research, Technical Report MSRTR-2011-116, jul. 2011, p. 10. Disponível em: $<$ https://www.researchgate.net/publication/221512843_What_Is_an_Algorithm>. Acesso em: 14 abr. 2019.

GUSTAFSSON, Håkan. Fiction of law. Rechtstheorie 41 (2010), S. 319-363. Duncker \& Humblot, Berlin.

G1. Uber pagará US\$20 milhões em acordo com motoristas nos EUA: Processo é sobre vínculo trabalhista. Valor ficou bem abaixo do que o da proposta inicial feita pela empresa, em 2016, que juiz considerou inadequada, 13 mar. 2019. Disponível em: <https://g1.globo.com/economia/tecnologia/noticia/2019/03/12/uber-pagara-us20-milhoes-em-acordo-com-motoristas-nos-eua.ghtml>. Acesso em: 14 mar. 2019.

- Justiça reafirma vínculo trabalhista entre Uber e motoristas no Reino Unido: empresa havia recorrido da decisão de 2016, mas sofreu nova derrota, 19 dez. 2018. Disponível em:

<https://g1.globo.com/economia/tecnologia/noticia/2018/12/19/justica-reafirmavinculo-trabalhista-entre-uber-e-motoristas-no-reino-unido.ghtml>. Acesso em: 14 mar. 2019.

HARET, Florence Cronemberger. Presunções em direito tributário: teoria e prática. 2010. 651 f. Tese (Doutorado em Direito Econômico e Financeiro)-Universidade de São Paulo, São Paulo, 2010. Disponível em: 
<http://www.teses.usp.br/teses/disponiveis/2/2133/tde-28012011-090558/pt-br.php>. Acesso em: 19 dez. 2017.

HEIDEGGER, Martin. Heráclito: a origem do pensamento ocidental: lógica: a doutrina heraclítica do lógos. Tradução de Marcia Sá Cavalcante Schuback. Rio de Janeiro: Relume Dumará, 1998.

- The question concerning technology, and other essays. Tradução de William Lovitt. New York: Harper \& Row, 1977

HIGA, Flávio da Costa. Reforma trabalhista e contrato de trabalho intermitente. Revista Consultor Jurídico, 8 de junho de 2017. Disponível em:

<http://www.conjur.com.br/2017-jun-08/flavio-higa-reforma-trabalhista-contratotrabalho-intermitente\#author>. Acesso em: 2 out. 2017.

HOUAISS, Antônio et al. Grande dicionário Houaiss. Disponível em: <http://houaiss.uol.com.br>. Acesso em: 6 set. 2017.

HUBERMAN, Leo. História da riqueza do homem. Tradução de Waltensir Dutra e atualização de Marcia Guerra. 22. ed. Rio de Janeiro: LTC, 2017.

HUMANISTA. Casos de violência em 2018 assustam e motoristas de aplicativo exigem mudanças, 24 out. 2018. Disponível em:

<https://www.ufrgs.br/humanista/2018/10/24/casos-de-violencia-em-2018-assustame-motoristas-de-aplicativo-exigem-mudancas/>. Acesso em: 02 maio 2019.

IHU ON-LINE. Ralés, batalhadores e uma nova classe média: entrevista especial com Jessé de Souza. 23 jan. 2011. Disponível em:

$<$ http://www.ihu.unisinos.br/entrevistas/40127-rales-batalhadores-e-uma-novaclasse-media-entrevista-especial-jesse-de-souza\#>. Acesso em: 2 jan. 2019.

ICHINO, Pietro. Una legge per i platform workers e per le umbrella companies. 10 fev. 2017. Disponível em: <https://www. pietroichino.it/? $p=46512 \&$ print=1>. Acesso em: 02 maio 2019.

IL COMUNE. Domino's Pizza firma la "Carta dei diritti fondamentali del lavoro digitale nel contesto urbano", 21 mar. 2019. Disponível em:

$<$ http://www.comune.bologna.it/news/domino-pizza-carta-diritti-fondamentali-lavorodigitale-riders-piattaforme>. Acesso em: 11 out. 2019.

INTERNATIONAL LABOUR OFFICE (ILO). OIT: quase dois terços da força de trabalho global estão na economia informal. 2 maio 2018. Disponível em: <https://www.ilo.org/brasilia/noticias/WCMS_627643/lang--pt/index.htm>. Acesso em: 2 jan. 2019.

JANSEN, Carlos. Aventuras maravilhosas do celeberrimo Barão de Munchhausen ou fiel e veridica narrativa das memorias extraordinarias e aventuras admiraveis daquelle narrador imortal. Rio de Janeiro: Laemmert \& C, 1902, p. 46-47. Disponível em: <https://digital.bbm.usp.br/handle/bbm/6744>. Acesso em: 22 set. 2019.) 
JOHANSON, Mark. EUA: o país das oportunidades... e das férias não remuneradas. BBC Capital, 20 nov. 2014. Disponível em: < https://www.bbc.com/portuguese/noticias/2014/11/141112_vert_cap_ferias_dg. Acesso em: 28 mar. 2019.

JOHNSON, Madeleine. Who are Uber's biggest competitors? Nasdaq, 17 out. 2017. Disponível em: <http://www.nasdaq.com/article/who-are-ubers-biggest-competitorscm860923>. Acesso em: 19 jan. 2018.

JORNAL JOSEENSE NEWS. Aplicativo Bella Driver terá motorista contratado pela CLT a partir de 1ำ de maio, Dia Internacional do Trabalho, 16 abr. 2019. Disponível em: <https://jornaljoseensenews.com.br/aplicativo-bella-driver-tera-motoristacontratado-pela-clt-a-partir-de-10-de-maio-dia-internacional-do-trabalho/>. Acesso em: 11 out. 2019.

KELLER, Alfred Josef. Michaelis dicionário escolar alemão. São Paulo:

Melhoramentos, 2016. Disponível em: <http://michaelis.uol.com.br/>. Acesso em: 15 jan. 2018.

KELLY, J. N. D. Early christian doctrines. 4. ed. Londres: Adam \& Charles Black, 1968.

KELSEN, Hans. Teoria pura do direito. Tradução de João Baptista Machado. 3. ed. São Paulo: Martins Fontes, 1991.

Teoria geral das normas. Tradução de José Florentino Duarte. Porto Alegre: Fabris, 1986.

KJELD, Jakobsen; MARTINS, Renato; DOMBROWSKI, Osmir. (Orgs.). Mapa do trabalho informal. São Paulo: Fundação Perseu Abramo, 2000. Disponível em: $<$ http://csbh.fpabramo.org.br/uploads/mapa_do_trabalho_informal.pdf>. Acesso em: 10 abr. 2018.

KLEINBERG, Jon. The mathematics of algorithm design. Cornell University, Ithaca NY, USA. Disponível em:

<http://www.cs.princeton.edu/ chazelle/courses/BIB/kleinberg-algo-design.pdf>. Acesso em: 14 abr. 2019.

KLEINA, Nilton. A história da deep web, o submundo da internet [vídeo]. Tecmundo, 03 jul. 2018. Disponível em: <https://www.tecmundo.com.br/internet/131843-historiadeep-web-submundo-da-internet-video.htm>. Acesso em: 22 out. 2018.

KOJIKOVSKI, Gian. "O Uber não é solução para o trânsito lento”: Para Philipp Rode, diretor do centro de pesquisa sobre cidades da London School of Economics, é preciso cobrar imposto de quem anda de carro nas metrópoles. Revista exame, 31 mar. 2016. Disponível em: <https://exame.abril.com.br/revista-exame/o-uber-naoe-solucao-para-o-transito-lento/>. Acesso em: 18 jan. 2018.

$\mathrm{KOHN}$, Stephanie. Tech Moms: elas criaram startups inovadoras e ficaram mais perto dos filhos. Canaltech, 12 maio 2017. Disponível em: 
$<$ https://canaltech.com.br/carreira/tech-moms-elas-criaram-startups-inovadoras-eficaram-mais-perto-dos-filhos-93668/>. Acesso em: 19 jan. 2018.

KREPSKY, Giselle Marie. ROCHA, Leonel Severo. Regulação tecnocientífica: Direito e ciência na sociedade complexa. RVMD, Brasília, V. 10, № 2, p. 264-286, jul.-dez., 2016. Disponível em:

$<$ https://portalrevistas.ucb.br/index.php/rvmd/article/viewFile/7027/4783>. Acesso em: 17 mar. 2018.

LALANDE, André. Vocabulário técnico e crítico da filosofia. Vol. I. Tradução de Fátima Sá Correia et al. Porto: Rés, 1999.

LAROUSSE.FR. Disponível em: <https://www.larousse.fr/>. Acesso em: 14 abr. 2019.

LAVOROSì. Carta dei diritti fondamentali del lavoro digitale urbano, 4 jun. 2018. Disponível em: <http://www.lavorosi.it/relazioni-sindacali-e-contratti-collettivi/sistemacontrattuale-e-livelli-di-contrattazione/carta-dei-diritti-fondamentali-del-lavoro-digitaleurbano/>. Acesso em: 11 out. 2019.

- Tribunale di Torino: i food-rider sono lavoratori autonomi perché non obbligati ad effettuare la prestazione, 8 maio 2018. Disponível em:

$<$ http://www.lavorosi.it/rapporti-di-lavoro/tipologie-contrattuali/tribunale-di-torino-ifood-rider-sono-lavoratori-autonomi-perche-non-obbligati-ad-effettuare-la-pr/>. Acesso em: 11 out. 2019.

LEE, Dave. Mulheres dirigindo Uber: 'Somos entregues aos lobos', dizem motoristas sobre assédio sexual. BBC News, 11 fev. 2019. Disponível em:

<https://www.bbc.com/portuguese/geral-47041534>. Acesso em: 26 maio 2019.

LEITE, Carlos Henrique Bezerra. Os direitos da personalidade na perspectiva dos direitos humanos e do direito constitucional do trabalho. In: BRAMANTE, Ivani Contini; CALVO, Adriana (Orgs.). Aspectos polêmicos e atuais do direito do trabalho: homenagem ao professor Renato Rua de Almeida. São Paulo: LTr, 2007, p. 37-53.

LEME, Ana Carolina Reis Paes. Da máquina à nuvem: o caso Uber sob a perspectiva do Direito do trabalho pós-material. In BARRETO, Daniel Arêa Leão et al. (Coords.). Direito e processo do trabalho: temas de acordo com a reforma trabalhista. São Paulo: LTr, 2019, p. 63-72. E-book.

- UBER e o uso do marketing da economia colaborativa. In LEME, Ana Carolina Reis Paes et al. (Coords.). Tecnologias disruptivas e a exploração do trabalho humano. São Paulo: LTr, 2017, p. 77-88. E-book.

LEXICO.COM. Disponível em: <https://www.lexico.com>. Acesso em: 8 out. 2019.

LIMA, Gabriela Miranda de. Reforma trabalhista e os institutos limitadores à construção jurisprudencial. Revista do Tribunal Regional do Trabalho da $21^{\text {a }}$ Região, no 18, 2018, p. 101-118. Disponível em: 
<http://ead.trt21.jus.br/pluginfile.php/5765/mod_resource/content/1/Revista\%20TRT2 1\%20-\%202018.pdf>. Acesso em: 5 set. 2018.

LIMA, Welton Dias de. Computadores e inteligência: uma explicação elucidativa sobre o teste de turing. Revista Outras Palavras, vol. 13, n. 1, ano 2017, p. 1-12. Disponível em:

<http://revista.faculdadeprojecao.edu.br/index.php/Projecao5/article/view/756/730>. Acesso em: 27 set. 2019.

LOSANO, Mario G. Os grandes sistemas jurídicos: introdução aos sistemas jurídicos europeus e extra-europeus. Tradução de Marcela Varjão. São Paulo: Martins Fontes, 2007.

LUHMANN, Niklas. Sistema jurídico y dogmática jurídica. Tradução de Luis E. Marcano Salazar et al. Santiago: Olejnik, 2018.

- La economía de la sociedad. Tradução de Aldo Mascareño. Cidade do México: Editorial Herder, 2017.

Sistemas sociais: esboço de
Costa et al. Petrópolis: Vozes, 2016.

—. Introdução à teoria dos sistemas. Tradução de Ana Cristina Arantes Nasser. Petrópolis: Vozes, 2009.

- La sociedad de la sociedad. Tradução de Javier Torres Nafarrate. Cidade do México: Herder e Universidad Iberoamericana, 2006.

El derecho de la sociedad. Tradução de Javier Torres Nafarrate. México: Herder e Universidad Iberoamericana, 2005.

A restituição do décimo segundo camelo: do sentido de uma análise sociológica do Direito. In Niklas Luhmann: do sistema social à sociologia jurídica. ARNAUD, André-Jean e LOPES JR, Dalmir (Orgs.). Rio de Janeiro: Lumen Juris, 2004.

- La ciencia de la sociedad. Tradução de Silvia Pappe et al. México, D.F.: Anthropos, Universidad Iberoamericana e ITESO, 1996.

A posição dos tribunais no sistema jurídico. Tradução de Peter Naumann, Ajuris, n. 49, Porto Alegre, 1990, p. 149-168.

- Ecological communication. Tradução de John Bednarz, Jr. Chicago: The University of Chicago Press, 1989.

Sociologia do Direito. V. II. Tradução de Gustavo Bayer. Rio de Janeiro: Tempo Brasileiro, 1985.

Sociologia do Direito. Vol. I. Tradução de Gustavo Bayer. Rio de Janeiro: Tempo Brasileiro, 1983. 
- Legitimação pelo procedimento. Tradução de Maria da Conceição CôrteReal. Brasília: Editora Universidade de Brasília, 1980.

MACHADO, Leandro. Dormir na rua e pedalar 12 horas por dia: a rotina dos entregadores de aplicativos. BBC News Brasil, 22 maio 2019. Disponível em: <https://www.bbc.com/portuguese/brasil-48304340>. Acesso em: 26 maio 2019.

MAEDA, Fabíola Miotto. Prestação de serviço por meio de pessoa jurídica: dignidade e fraude nas relações de trabalho. 2014, 149 f. Dissertação (Mestrado em Direito)-Universidade de São Paulo, São Paulo, 2014. Disponível em: <http://www.teses.usp.br/teses/disponiveis/2/2138/tde-21012015-080938/pt-br.php>. Acesso em: 10 abr. 2018.

MAGALHÃES, Alline et al. Lobistas de bancos, indústrias e transportes estão por trás das emendas da Reforma Trabalhista. The Intercept, 26 abr. 2017. Disponível em: <https://theintercept.com/2017/04/26/lobistas-de-bancos-industrias-etransportes-quem-esta-por-tras-das-emendas-da-reforma-trabalhista/>. Acesso em: 7 set. 2018.

MAGANO, Octavio Bueno. Manual de direito do trabalho: Direito individual do trabalho. V. II. 3. ed. São Paulo: LTr, 1992.

MALATESTA, Nicola Framarino Dei. A lógica das provas em matéria criminal. Vol. I. Tradução de Paolo. Capitanio. Bookseller, Campinas, 1996.

MCGREGOR, Moira; LAMPINEN, Airi; BROWN, Barry. Platform labour: algorithms versus business ethics. Mobile Life Centre, Stockholm University. Disponível em: $<$ https://algorithmsatwork.files.wordpress.com/2016/02/mcgregor-lampinen-brownplatform-labour-algorithms-versus-business-ethics-cscw-2016.pdf>. Acesso em: 14 abr. 2019.

MELO, Geraldo Magela. A uberização do trabalho doméstico. Limites e tensões. In LEME, Ana Carolina Reis Paes et al. (Coords.). Tecnologias disruptivas e a exploração do trabalho humano. São Paulo: LTr, 2017, p. 220-226. E-book.

MAIOR, Jorge Luiz Souto. A MP 808 caducou e levou com ela o seu assunto (a Lei n. 13.467/17). Carta Maior, 29 abr. 2018. Disponível em:

$<$ https://www.cartamaior.com.br/?/Editoria/Estado-Democratico-de-Direito/A-MP-808caducou-e-levou-com-ela-o-seu-assunto-a-Lei-n-13-467-17-/40/40042>. Acesso em: 5 set. 2018.

MANNRICH, Nelson. (Coord.). Reforma trabalhista: reflexões e críticas. São Paulo: LTr, 2018.

. Futuro do Direito do trabalho, no Brasil e no mundo. São Paulo: Revista LTr. Vol. 81, no 11, nov. 2017, p. 1287-1300.

Reforma trabalhista. Que reforma? In: AGUIAR, Antonio Carlos. (Coord.). Reforma trabalhista: aspectos jurídicos. Quartier Latin do Brasil, 2017, p. 229-255. 
. Reinventando o direito do trabalho: novas dimensões do trabalho autônomo. In FREDIANI, Yone. (Coord.). A valorização do trabalho autônomo e a livreiniciativa. Porto Alegre: Magister, 2015, p. 229-255.

. Relações de trabalho autônomo e subordinado: proposta para instituir critérios para sua distinção. In: BRAMANTE, Ivani Contini; CALVO, Adriana. (Orgs.). Aspectos polêmicos e atuais do Direito do trabalho. Estudos em homenagem ao Professor Renato Rua de Almeida. São Paulo: LTr, 2007. P 151-169.

Pluralismo jurídico e direito do trabalho. Revista do Advogado, São Paulo, v. 22, № 66, jun. 2002, p. 7-18.

. Dispensa coletiva: da liberdade contratual à responsabilidade social. São Paulo: LTr, 2000. E-book.

A modernização do contrato de trabalho. São Paulo: LTr, 1998.

MANNRICH, Nelson; ANDRADE, Tatiana Guimarães Ferraz. Economia colaborativa e empresas de mobilidade urbana: uma visão positiva. Jota, 14 mar. 2018.

Disponível em: <https://www.jota.info/opiniao-e-analise/artigos/economiacolaborativa-e-empresas-de-mobilidade-urbana-uma-visao-positiva-14032018>. Acesso em: 21 mar. 2018.

MARCO AURÉLIO. Meditações. Tradução de Thainara Castro. Brasília: Editora Kiron, 2011.

MARQUES, Claudia Lima. Contratos no código de defesa do consumidor: o novo regime das relações contratuais. 9. ed. São Paulo: Revista dos Tribunais, 2019.

MARTí, Silas. EUA apertam o cerco contra o Facebook: comissão investiga repasses de dados de usuários a consultoria que ajudou a eleger Trump. Folha de São Paulo, 21 mar. 2018. Disponível em:

<https://www1.folha.uol.com.br/mercado/2018/03/eua-apertam-o-cerco-contra-ofacebook.shtml>. Acesso em: 21 mar. 2018.

MARTINS, Sergio Pinto. Manual do trabalho doméstico. 12. ed. São Paulo: Atlas, 2013.

MARTINEZ, Luciano; BOUCINHAS FILHO, Jorge Cavalcanti; SILVA, Bruno Freire e. Curso de Direito processual do trabalho: homenagem da Academia Brasileira de Direito do Trabalho a Christovão Piragibe Tostes Malta e Wagner D. Giglio. São Paulo: LTr, 2019.

MARTINEZ, Luciano; MALTEZ, Mariana. O direito fundamental à proteção em face da automação. Revista de Direito do Trabalho, vol. 182/2017, p. 21-59, out. 2017. Disponível em:

<http://www.academia.edu/37646783/O_DIREITO_FUNDAMENTAL_\%C3\%80_PRO TE\%C3\%87\%C3\%83O_EM_FACE_DA_AUTOMA\%C3\%87\%C3\%83O_The_Funda 
mental_Right_To_Protection_In_The_Face_Of_Automation_>. Acesso em: 4 mar. 2019.

MARTINS-COSTA, Judith Hofmeister. O direito privado como um "sistema em construção": as cláusulas gerais no projeto do Código Civil brasileiro. Jus Navigandi, Teresina, a. 4, n. 41, mai. 2000. Disponível em:

<http://www1.jus.com.br/doutrina/texto.asp?id=513>. Acesso em: 23 fev. 2004.

MEDEIROS, Aline Barreira. Aposentadoria por idade rural, Jus Brasil, 2018.

Disponível em:

$<$ https://alinebmedeiros.jusbrasil.com.br/artigos/514105830/aposentadoria-por-idaderural>. Acesso em: 16 maio 2018.

MEI: quem se formaliza tem direito à previdência social: entenda como funciona o direito à aposentadoria para o microempreendedor individual. Pequenas empresas \& grandes negócios, 29 jul. 2019. Disponível em:

$<$ https://revistapegn.globo.com/MEl/noticia/2019/07/mei-quem-se-formaliza-temDireito-previdencia-social.html>. Acesso em: 14 ago. 2019.

MEIRELES, Cecília. Ou isto ou aquilo. Pensador. Disponível em: <https://www.pensador.com/frase/NTU0ODE0/>. Acesso em: 17 out. 2019.

MEIRELLES, Hely Lopes. Direito administrativo brasileiro. Atualizada por Eurico de Andrade Azevedo, Délcio Balestero Aleixo e José Emmanuel Burle Filho. 17. ed. São Paulo: Revista dos Tribunais, 1992.

MELO, Luísa. Após aporte de US\$2,1 bi, Uber já vale mais que Ford ou GM: entre os investidores que apostaram na companhia estariam os fundos Tiger Global Capital Management e T. Rowe Price, segundo o The Wall Street Journal. Revista Exame. 1 jun. 2016. Disponível em: <https://exame.abril.com.br/negocios/comaporte-de-us-2-1-bi-uber-ja-vale-mais-que-ford-ou-gm/>. Acesso em: 15 jan. 2018.

MESSIAS, Carlos Jornalista virou Uber por um mês e lucrou só 30 reais por dia: repórter descobriu os percalços da profissão e as trapaças dos motoristas do aplicativo para aumentar o rendimento. Veja São Paulo, 4 abr. 2017. Disponível em: <https://vejasp.abril.com.br/cidades/uber-teste-motorista-um-mes/>. Acesso em: 18 maio 2019.

MIRANDA, Pontes de. Tratado de direito privado. T. 48. Atualizado por Vilson Rodrigues Alves. Campinas: Bookseller, 2007.

- Comentários ao Código de Processo Civil. 4. ed. Vol. IV. Rio de Janeiro: Forense, 1996.

MIZIARA, Raphael. Moderno dicionário de direito do trabalho. São Paulo: LTr, 2019. E-book.

MOEDAS, Carlos. "Estamos entrando na terceira fase da internet". Valor econômico, em 11 dez. 2015. Entrevista concedida a Diogo Schelp. Disponível em: 
<http://www.bv.fapesp.br/namidia/noticia/116746/estamos-entrando-na-terceira-faseda-internet/>. Acesso em: 15 jan. 2018.

MONTEIRO, Lilian. Profissional sem vínculo empregatício: caminho sem volta no mercado de trabalho. Jornal Estado de Minas, 8 mar. 2018. Disponível em: <https://www.em.com.br/app/noticia/emprego/2018/03/08/interna_emprego,942752/p rofissional-sem-vinculo-empregaticio-caminho-sem-volta.shtml >. Acesso em: 12 jul. 2018.

MORAES, Alexandre de. Reforma política do estado e democratização. Revista da Procuradoria Geral do Estado de São Paulo, n. 51/52, p. 103-133, jan./dez., 1999. Disponível em: <http://www.pge.sp.gov.br/centrodeestudos/revistaspge/revista5/5rev5.htm>. Acesso em: 5 set. 2018.

MORIN, Edgar. O método 1: a natureza da natureza. Tradução de Maria Gabriela de Bragança. 2. ed. Mira-Sintra: Publicações Europa-América, 1977.

MOTHA, Stewart. Soberanía "postcolonial" y el evento de la pluralidade. In CORREAS, Oscar. (Coord.). Pluralismo jurídico: otros horizontes. México, D.F.: Ediciones Coyocán, 2007, p. 249-278.

NAÇÕES UNIDAS. OIT: países devem agir para que inovações criem oportunidades no mundo do trabalho, 22 jan. 2019. Disponível em: $<$ https://nacoesunidas.org/oit-paises-devem-agir-para-que-inovacoes-criemoportunidades-no-mundo-do-trabalho/>. Acesso em: 12 out. 2019.

NAPOLI, Gaetano Edoardo; MOLLO, Antonio. II lavoro subordinato per la giurisprudenza. Professionistilegali. Disponível em:

$<$ https://professionistilegali.wordpress.com/diritto-del-lavoro/il-lavoro-subordinato-perla-giurisprudenza/>. Acesso em: 12 set. 2017.

NASCIMENTO, Amauri Mascaro. Parecer Dr. Amauri Mascaro Nascimento, de 18 de março de 2010. Disponível em:

<http://sintecsp.org.br/boletins/PARECER_DR.AMAURI_MASCARO_NASCIMENTO. pdf>. Acesso em: 22 ago. 2019.

Curso de direito do trabalho. 24. ed. São Paulo: Saraiva, 2009.

A competência da Justiça do Trabalho para a relação de trabalho. In COUTINHO, Grijalbo Fernandes; FAVA, Marcos Neves (Coords.). Nova competência da Justiça do Trabalho. São Paulo: LTr, 2005, p. 24-37.

NERY JUNIOR, Nelson. Contratos no Código Civil. In: FRANCIULLI NETO, Domingos; MENDES, Gilmar F., MARTINS FILHO, Ives Gandra S. (Coords.). $O$ novo Código Civil: homenagem ao professor Miguel Reale. 2. ed. São Paulo: LTr, 2003.

NEVES, Marcelo. Transconstitucionalismo. São Paulo: Martins Fontes, 2009. 
A constitucionalização simbólica. 2. ed. São Paulo: Martins Fontes, 2007.

NIETZSCHE, Friedrich. A filosofia na época trágica dos gregos. Tradução de Mara Inês Madeira de Andrade. Lisboa: Edições 70, 2018.

NUNES, Rizzatto. Curso de direito do consumidor. 5. ed. São Paulo: Saraiva, 2010.

NUNES, Ruy Afonso da Costa. Santo Agostinho e o menino. Revista da Faculdade de Educação da USP. V. 1, n. 1, 01 dez. 1975, p. 157-163. Disponível em:

<http://www.revistas.usp.br/rfe/article/view/33207/35945>. Acesso em: 20 jun. 2019.

O GLOBO. Motoristas da Uber se juntam para burlar algoritmo e aumentar preços das corridas, 03 ago. 2017. Disponível em:

$<$ https://extra.globo.com/noticias/economia/motoristas-da-uber-se-juntam-para-

burlar-algoritmo-aumentar-precos-das-corridas-21665464.html>. Acesso em: 30 set. 2019.

$\mathrm{OH}$, Se Hyeon. Uber pagará US\$20 milhões a motoristas em acordo de processo judicial. Canaltech, 13 mar. 2019. Disponível em:

$<$ https://canaltech.com.br/juridico/uber-pagara-us-20-milhoes-a-motoristas-emacordo-de-processo-judicial-134621/>. Acesso em: 14 mar. 2019.

OIT. Declaração da OIT sobre os princípios fundamentais no trabalho e seu seguimento. Disponível em:

<https://www.ilo.org/brasilia/publicacoes/WCMS_230648/lang--pt/index.htm>. Acesso em: 28 mar. 2019.

OLIVEIRA, Carol. Empresas de transporte por aplicativo travam disputa por novas regras no brasil; entenda: enquanto briga com a prefeitura em Nova York, empresa de transporte por app enfrenta novas regulações na capital paulista. Revista Autoesporte, 21 fev. 2019. Disponível em:

$<$ https://revistaautoesporte.globo.com/Noticias/noticia/2019/02/uber-99-cabifyempresas-de-transporte-por-aplicativo-travam-disputa-por-novas-regras-no-brasilentenda.html>. Acesso em: 17 maio 2019.

OLIVEIRA, Carol et al. Exame: a economia dos apps, Locomotiva, 17 abr. 2019. Disponível em: <https://www.ilocomotiva.com.br/single-post/2019/04/17/EXAME-AEconomia-dos-Apps>. Acesso em: 19 out. 2019.

OLIVEIRA, Filipe. Chinesa Didi Chuxing compra 99, que é avaliado em mais de US\$ 1 bilhão. Folha de São Paulo, 3 jan. 2018. Disponível em:

<http://www1.folha.uol.com.br/mercado/2018/01/1947777-chinesa-didi-chuxingconfirma-compra-de-app-de-corridas-99.shtml>. Acesso em: 19 jan. 2018.

OLIVEIRA, Murilo Carvalho Sampaio. Relação de emprego, dependência econômica \& subordinação jurídica: revisitando conceitos - critérios de identificação do vínculo empregatício. Curitiba: Juruá, 2014. 
OLIVIER, Jean-Michel. La requalification en contrat de travail. Dalloz, Paris, 16 mar. 2017. Disponível em: <https://actu.dalloz-etudiant.fr/focus-sur/article/larequalification-en-contrat-de-travail/h/e53c7c83465133a02a85d5fd242de625.html>. Acesso em: 2 jun. 2018.

OLGIATI, Vittorio. Direito positivo e ordens sociojurídicas: um "engate operacional" para uma sociologia do Direito europeia. In FARIA, José Eduardo. (Org.). Direito e globalização econômica: implicações e perspectivas. São Paulo: Malheiros, 2015, p. 81-104.

O'NEILL, Patrick Howell. Motoristas de Uber exigem melhores pagamentos em manifestação nos EUA; brasileiros também protestam. Gizmodo Brasil, 9 maio 2019. Disponível em: <https://gizmodo.uol.com.br/motoristas-de-uber-exigemmelhores-pagamentos-em-manifestacao-nos-eua-brasileiros-tambem-protestam/>. Acesso em: 26 maio 2019.

ORTELLADO, Pablo. Está na hora de regular a Uber? Nova lei do estado da Califórnia deve reclassificar o trabalho com Uber como emprego. Folha de São Paulo, 17 set. 2019. Disponível em: <https://www1.folha.uol.com.br/colunas/pabloortellado/2019/09/esta-na-hora-de-regular-a-uber.shtml?loggedpaywall>. Acesso em: 28 set. 2019.

OS PRÉ-SOCRÁTICOS: vida e obra. São Paulo: Nova Cultural, 1996. (Coleção Os pensadores).

OST, François. O tempo do Direito. Tradução de Maria Fernanda Oliveira. Lisboa: Instituto Piaget, 1999.

OXFORD ENGLISH DICTIONARY. Disponível em: < https://en.oxforddictionaries.com/definition/gig_economy>. Acesso em: 28 mar. 2019.

PAGANINI, Pierluigi. The deep web: the internet's dark side. Encyclopædia Britannica, 13 jan. 2015. Disponível em: <https://www.britannica.com/topic/DeepWeb-The-Internets-Dark-Side-The-2010684>. Acesso em: 22 out. 2018.

PAPA LEÃO XIII. Rerum novarum. Disponível em: <http://w2.vatican.va/content/leoxiii/pt/encyclicals/documents/hf_I-xiii_enc_15051891_rerum-novarum.html>. Acesso em: 3 mar. 2019.

PAPINI, Giovanni. Sant'Agostino. Siena: Edizioni Cantagalli, 2011. Disponível em: <https://id.b-ok.org/book/2876327/a88625>. Acesso em: 20 jun. 2019.

PASQUIER, Thomas. Sens et limites de la qualification de contrat de travail: de l'arrêt FORMACAD aus travailleurs "ubérisés", Revue de Droit du Travail, Dalloz, Paris, fev. 2017, p. 95-109. Disponível em: <https://actu.dalloz-

etudiant.fr/fileadmin/actualites/pdfs/03.2017/RDT02-05_ETUDE2.pdf>. Acesso em: 2 jun. 2018. 
PASTORE, José. A batalha dos encargos sociais. Folha de São Paulo, 28 fev. 1996. Disponível em: <http://www.josepastore.com.br/artigos/rt/rt_082.htm>. Acesso em: 15 jan. 2018.

PEQUENAS EMPRESAS \& GRANDES NEGÓCIOS. Simples Nacional inclui motorista de aplicativo entre profissões do MEl: se o profissional optar pelo MEI, ele passa a contribuir para o INSS, com alíquota de $5 \%$ sobre o valor do salário mínimo, 8 ago. 2019. Disponível em:

$<$ https://revistapegn.globo.com/MEl/noticia/2019/08/pegn-simples-nacional-incluimotorista-de-aplicativo-entre-profissoes-do-mei.html>. Acesso em: 14 ago. 2019.

PERASSO, Valeria. O que é a 4⿳亠丷a revolução industrial - e como ela deve afetar nossas vidas. $B B C, 22$ out. 2016. Disponível em:

<http://www.bbc.com/portuguese/geral-37658309>. Acesso em: 27 maio 2017.

PERRIN, Fernanda. Flexibilidade no ambiente de trabalho ameaça topo da pirâmide. Folha de São Paulo, 21 jan. 2018. Disponível em:

<http://www1.folha.uol.com.br/mercado/2018/01/1952125-flexibilidade-no-ambientede-trabalho-ameaca-topo-da-piramide.shtml>. Acesso em: 21 jan. 2018.

PEREIRA, Caio Mário da Silva. Instituições de direito civil: contratos. Vol. III. Revista e atualizada por Regis Fichtner. 16. ed. Rio de Janeiro: Forense, 2012

_. Instituições de direito civil: introdução ao Direito civil. Teoria geral de Direito civil. Vol. I. Revista e atualizada por Maria Celina Bodin de Moraes. 21. ed. Rio de Janeiro: Forense, 2006.

PERRY, Marvin. Civilização ocidental: uma história concisa. Tradução de Waltensir Dutra e Silva Vieira. 4. ed. São Paulo: WMF Martins Fontes, 2015.

PICCOLOTTO, Letícia. O dia depois de amanhã: para onde iremos com o advento da tecnologia? Jota, 01 jan. 2019. Disponível em: <https://www.jota.info/coberturasespeciais/inova-e-acao/o-dia-depois-de-amanha-para-onde-iremos-com-o-adventoda-tecnologia-01012019>. Acesso em: 2 jan. 2019.

PINHEIRO, Gabriel. Estudo aponta que tecnologia é a chave para mais empregos no futuro: Pesquisa elaborada pelo Senai mostra que vagas para profissionais com domínio de processos tecnológicos são as que terão maior oferta na indústria, nos próximos anos. Conhecimento de áreas diversas será fundamental para se manter no mercado. Correio Brasiliense, 12 ago. 2019. Disponível em:

<https://www.correiobraziliense.com.br/app/noticia/economia/2019/08/12/internas_ec onomia,776697/estudo-aponta-que-tecnologia-e-a-chave-para-mais-empregos-nofuturo.shtml>. Acesso em: 14 ago. 2019.).

PINTO, José Augusto Rodrigues. O destino do homem no mundo novo da inteligência artificial. Manuscrito do autor, Salvador, 15 out. 2018, 13 f.

1417-1428, dez. 2004 .
14tor tecno 
. Curso de direito individual do trabalho. 5. ed. São Paulo: LTr, 2003.

PINTO, José Augusto Rodrigues; MARTINEZ, Luciano; MANNRICH, Nelson. (Coords.). Dicionário brasileiro de direito do trabalho. São Paulo: LTr, 2013.

PIQUET, Igor. Como um negócio sai do voo de pato para o salto do unicórnio? Folha de São Paulo, 21 jan. 2018. Disponível em:

<http://www1.folha.uol.com.br/mercado/2018/01/1951808-como-um-negocio-sai-dovoo-de-pato-para-o-salto-do-unicornio.shtml>. Acesso em: 21 jan. 2018.

PITOZZI, Andrea. II ministro del Lavoro vuole riscrivere la legge sui rider: più tutele, salario garantito e una piattaforma unica per i contratti, gestita dall'Inps (come anticipato in esclusiva da Wired), sono i tre punti avanzati dalla ministra Nunzia Catalfo. Wired.it, 30 set. 2019. Disponível em:

<https://www. wired.it/economia/lavoro/2019/09/30/rider-ministro-

lavoro/?refresh_ce=>. Acesso em: 10 out. 2019.

PORTALIS, Jean-Étienne-Marie. Discours préliminaire du premier projet de Code civil (1801). Bordeaux: Éditions Confluences, 2004, p. 24. Disponível em:

$<$ http://mafr.fr/lMG/pdf/discours_1er_code_civil.pdf>. Acesso em: 5 set. 2018.

PORTO, Lorena Vasconcelos. A parassubordinação como forma de discriminação. Actualidad jurídica iberoamericana, IDIBE, núm. 6, feb. 2017, p. 228-242. Disponível em: <http://idibe.org/wp-content/uploads/2013/09/11._Lorena_Vasconcelos_pp._228242.pdf>. Acesso em: 16 maio 2018.

A parassubordinação: proteção ou discriminação. In: RENAULT, Luiz Otávio Linhares et al. (Coords.). Discriminação. 2. ed. São Paulo, LTr, 2010, p. 164-175.

PRATA, Marcelo Rodrigues. Os elementos essenciais da sentença articulados com os precedentes no futuro CPC e seus reflexos no processo trabalhista. In: CONGRESSO INTERNACIONAL DE DIREITO DO TRABALHO, 4., 2014, São Paulo. Anais [...]. In MANNRICH, Nelson et al. (Coords.). Reinvenção do direito do trabalho: crise econômica e desajustes sociais. Porto Alegre: Lex Magister, 2015, p. 300-314.

O direito ambiental do trabalho numa perspectiva sistêmica: as causas da inefetividade da proteção à ambiência laboral e o que podemos fazer para combatêla. São Paulo: LTr, 2013.

O direito ambiental do trabalho numa perspectiva sistêmica. 2011. $380 \mathrm{f}$. Dissertação (Mestrado em Direito)-Pontifícia Universidade Católica de São Paulo, São Paulo, 2011.

PROCHNO, Pedro. Fatos e dados sobre a Uber, Uber, 5 jan. 2018. Disponível em: <https://www.uber.com/pt-BR/newsroom/fatos-e-dados-sobre-uber/>. Acesso em: 18 jan. 2018. 
PUCERO, Zuleta. O processo de globalização e a reforma do estado. In FARIA, José Eduardo. (Org.). Direito e globalização econômica: implicações e perspectivas. São Paulo: Malheiros, 2015, p. 105-126.

QUEIROZ, Antônio Augusto. Passado, presente e futuro do Centrão, a oposição conservadora no Congresso. Consultor Jurídico, 31 jul. 2018. Disponível em: $<$ https://www.conjur.com.br/2018-jul-31/antonio-queiroz-passado-presente-futurocentrao>. Acesso em: 8 set. 2018.

RAMALHO, Maria do Rosário Palma. Direito do trabalho: parte II — situações laborais individuais. 3. ed. Coimbra: Almedina, 2010.

—_. Direito do trabalho: parte I — dogmática geral. Coimbra: Almedina, 2005.

RAWLS, John. The justification of civil disobedience. In RAWLS, John. Collected papers. Edited by Samuel Freeman. Cambridge, Massachusetts: Harvard University Press, 1999.

RAY, Jean-Emmanuel. Droit du travail droit vivant. 17. ed. Paris: Editions Liasions, 2008.

REALE, Miguel. Visão geral do novo Código Civil. Jus Navigandi, Teresina, ano 6, n. 54, fev. 2002. Disponível em: <http://jus.uol.com.br/revista/texto/2718>. Acesso em: 05 mar. 2009.

A boa-fé no Código Civil. Disponível em:

<http://www.miguelreale.com.br/index.html>. Acesso em: 1ํo mar. 2007.

—. Lições preliminares de direito. 25. ed. São Paulo: Saraiva, 2001.

—. Introdução à filosofia. 3. ed. São Paulo: Saraiva, 1994.

REVISTA AUTOESPORTE. Uber. conheça a história e polêmicas da empresa de transporte. 28 abr. 2017. Disponível em:

$<$ https://revistaautoesporte.globo.com/Noticias/noticia/2017/04/uber-conhecahistoria-e-polemicas-da-empresa-de-transporte.html>. Acesso em: 12 jul. 2018.

RIBEIRO, Felipe. Uber é avaliada em US\$ 82 bilhões após abertura de capital. Canaltech, 10 maio 2019. Disponível em: <https://canaltech.com.br/bolsa-devalores/uber-e-avaliada-em-us-82-bilhoes-apos-abertura-de-mercado-138929/>. Acesso em: 28 set. 2019.

RIVISTA TELEMATICA DI DIRITTO DEL LAVORO. D.Lgs. 276/03 attuazione L. 30/03 (legge Biagi) (aggiornato alla L. 92/12). Disponível em: <http://www.dielle.it/leggi-voce-menu/174-d-lgs-276-03-attuazione-l-30-03-legge-biagi-aggiornatoalla-I-92-12>. Acesso em: 20 out. 2019.

ROBERTO, Enrico; RAMPAZZO, Renato. O que muda com a regulamentação dos aplicativos de transporte? Promulgação da lei abriu espaço para municípios e o distrito federal regularem a matéria. Jota, 22 abr. 2018. Disponível em: 
<https://www.jota.info/opiniao-e-analise/artigos/o-que-muda-com-a-regulamentacaodos-aplicativos-de-transporte-22042018>. Acesso em: 12 jul. 2018.

ROCHA, Leonardo. Olho infernal: software "Hell" da Uber espionava motoristas da rival Lyft. Tecmundo, 15 abr. 2017. Disponível em:

$<$ https://www.tecmundo.com.br/uber/115829-olho-infernal-software-hell-uberespionava-motoristas-da-rival-lyft.htm>. Acesso em: 24 jan. 2018.

RODRIGUES, Larissa. Contrariando Maia, Temer finalmente assina MP da reforma trabalhista: Presidente da Câmara defendia que um projeto de lei fosse enviado ao Congresso. Já o presidente optou pela MP, como prometido ao Senado. Metrópoles, 14 nov. 2017. Disponível em: <https://www.metropoles.com/brasil/politica-br/contrariando-maia-temer-finalmenteassina-mp-da-reforma-trabalhista>. Acesso em: 5 set. 2018.

REIS, Daniela Muradas; CORASSA, Eugênio Delmaestro. Aplicativos de transporte e plataforma de controle: o mito da tecnologia disruptiva do emprego e a subordinação por algoritmos. In LEME, Ana Carolina Reis Paes et al. (Coords.). Tecnologias disruptivas e a exploração do trabalho humano. São Paulo: LTr, 2017, p. 157-165. E-book.

REQUIÃO, Rubens. Curso de direito comercial. Vol. 1. 13. ed. São Paulo: Saraiva, 1984.

RIBEIRO, Gabriel Francisco. Destino do passageiro e sem papo com motorista: Uber terá mudanças em breve. UOL, 16 maio 2019. Disponível em:

<https://noticias.uol.com.br/tecnologia/noticias/redacao/2019/05/16/destino-dopassageiro-e-sem-papo-com-motorista-uber-tera-mudancas-em-breve.htm>. Acesso em: 26 maio 2019.

RODRIGUES, Silvio. Direito civil: parte geral. Vol. I. 32. ed. São Paulo: Saraiva, 2002.

. Direito civil: dos contratos e das declarações unilaterais da vontade. Vol. III. 19. ed. São Paulo: Saraiva, 1990.

RODRIGUEZ, Américo Plá. Princípios de direito do trabalho. Tradução de Wagner D. Giglio. São Paulo: LTr, 1993.

ROMITA, Arion Sayão. Direitos fundamentais nas relações de trabalho. 2. ed. São Paulo: LTr, 2007.

\section{O princípio da proteção em xeque. São Paulo: LTr, 2003. E-book.}

ROSA, Guilherme. Chegou a era dos transumanos: Decisão da Grã-Bretanha de permitir a geração de embriões com DNAs de três pessoas é saudada pelos defensores do transumanismo, que propõem romper os limites impostos ao homem por sua biologia. Veja, 8 mar. 2015. Disponível em: <https://veja.abril.com.br/ciencia/chegou-a-era-dos-transumanos/>. Acesso em: 16 maio 2018. 
ROTH, André-Noël. O direito em crise: fim do estado moderno? In FARIA, José Eduardo. (Org.). Direito e globalização econômica: implicações e perspectivas. São Paulo: Malheiros, 2015, p. 15-27.

RUPRECHT, Alfredo J. Os princípios do direito do trabalho. Tradução de Edilson Alkmin Cunha. São Paulo: LTr, 1995.

ROULAND, Norbert. Nos confins do direito: antropologia jurídica na modernidade. Tradução de Maria Ermantina de Almeida Prado Galvão. São Paulo: Martins Fontes, 2003.

RUSSELL, Bertrand. História da filosofia ocidental. Tradução de Brenno Silveira. São Paulo: Companhia Editora Nacional, 1957.

SANTO AGOSTINHO. 3. ed. São Paulo: Abril Cultural, 1984. (Coleção Os pensadores).

SANTO TOMÁS DE AQUINO. São Paulo: Nova Cultural, 2000. (Coleção Os pensadores).

SANTORO-PASSARELI, Giuseppe. Diritto dei lavori e dell'occupazione. 6. ed. Torino: Giappichelli, 2017.

SANTOS, Boaventura de Sousa. Pela mão de Alice: o social e o político na pósmodernidade. 11. ed. São Paulo: Cortez, 2006.

SANTOS, José Aparecido dos. Reformas trabalhistas na Itália: breve análise histórica e comparativa. In Rev. TST, São Paulo, vol. 83, no 4, out/dez 2017, p. 249271. Disponível em: <

https://siabi.trt4.jus.br/biblioteca/acervo/Doutrina/artigos/Revista\%20do\%20TST\%20v \%2083\%20n\%204\%202017/Reformas\%20trabalhistas\%20na\%20ltália\%20-

\%20breve\%20análise\%20histórica\%20e\%20corporativa.pdf>. Acesso em: 16 maio 2018.

SANTOS, Manoel dos. Principais tributos que incidem sobre as empresas de software e startups, Canaltech, 6 dez. 2013. Disponível em:

$<$ https://canaltech.com.br/mercado/airbnb-se-depara-com-obstaculos-que-podematrapalhar-planos-de-abrir-capital-152827/>. Acesso em: 18 out. 2019.).

SANTOS, Moacyr Amaral. Primeiras linhas de direito processual civil. Vol. II. 10. ed. São Paulo: Saraiva, 1985.

SANTOS, Roseniura; SOARES, Érica. O direito à proteção em face da automação e desemprego tecnológico: parâmetros constitucionais para regulamentação. In: CONGRESSO DE DIREITO E CONTEMPORANEIDADE: MIDIAS E DIREITOS DA SOCIEDADE EM REDE, 3‥, 2015, Santa Maria-RS. Anais [...]. Disponível em: <http://coral.ufsm.br/congressoDireito/anais/2015/6-20.pdf>. Acesso em: 4 mar. 2019. 
SARMENTO, Daniel. Ordem constitucional econômica, liberdade e transporte individual de passageiros: o "caso uber". Rio de Janeiro, 10 de julho de 2015. Disponível em: <https://www.conjur.com.br/dl/paracer-legalidade-uber.pdf>. Acesso em: 18 out. 2019.

SARTRE, Jean-Paul. O existencialismo é um humanismo. In Sartre: vida e pensamentos. São Paulo: Martin Claret, 1998, p. 89-139.

SAS. Internet das coisas (IoT): o que é e qual sua importância? Disponível em: $<$ https://www.sas.com/pt_br/insights/big-data/internet-das-coisas.html>. Acesso em: 26 out. 2018.

SATURNO, Ares. Nova York aprova lei inédita de salário mínimo para motoristas do Uber e Lyft. Canaltech, 5 dez. 2018. Disponível em:

$<$ https://canaltech.com.br/mercado/nova-york-aprova-lei-inedita-de-salario-minimopara-motoristas-do-uber-e-lyft-128365/>. Acesso em: 15 dez. 2018.

SCHUMPETER, Joseph A. Capitalism, socialism and democracy. NYC-London: Taylor \& Francis e-Library, 2003.

SCHWAB, Klaus. Novas tecnologias exigem governos preparados, diz líder de Davos. Folha de São Paulo, 30 jul. 2016. Entrevista concedida a Eliane Trindade. Disponível em: <http://www1.folha.uol.com.br/mercado/2016/07/1797012-novatecnologia-exige-governo-preparado-diz-lider-de-davos.shtml>. Acesso em: 27 maio 2017.

SILVA, Francisco de Assis e. O conceito de ficção jurídica na teoria do "como se" de Hans Vaihinger. 2011. 172 f. Dissertação (Mestrado em Filosofia)- Faculdade de São Bento, São Paulo, 2011. Disponível em:

$<$ http://faculdadedesaobento.com.br/files/pesquisas_12633716-10215796-8990-

052015.pdf>. Acesso em: 6 set. 2017.

SILVA, Lucília Lopes. A pessoa e sua humana dignidade. Clubjus, Brasília-DF: 11 jul. 2008. Disponível em: <http://www.clubjus.com.br/?content=2.19697>. Acesso em: 21 jun. 2010.

SILVA, Otavio Pinto e. Subordinação, autonomia e parassubordinação nas relações de trabalho. São Paulo: LTr, 2004. E-book.

SILVEIRA, Marcelo Deiro Prates da. Efeitos da globalização e da sociedade em rede via Internet na formação de identidades contemporâneas. Psicologia: ciência e profissão, Brasília, v. 24, n. 4, p. 42-51, dez. 2004. Disponível em:

$<$ http://www.scielo.br/scielo.php?script=sci_arttext\&pid=S1414-

98932004000400006 >. Acesso em: 22 out. 2018.

SCHWARCZ, Lilia M.; STARLING, Heloisa M. Brasil: uma biografia. São Paulo: Companhia das Letras, 2015.

SCHWAB, Klaus. Novas tecnologias exigem governos preparados, diz líder de Davos. Folha de São Paulo, 30 jul. 2016. Entrevista concedida a Eliane Trindade. 
Disponível em: <http://www1.folha.uol.com.br/mercado/2016/07/1797012-novatecnologia-exige-governo-preparado-diz-lider-de-davos.shtml>. Acesso em: 27 maio 2017.

A quarta revolução industrial. Tradução de Daniel Moreira Miranda. São Paulo: Edipro, 2016.

SIGNES, Adrián Todolí. O mercado de trabalho no século XXI: on-demand economy, crowdsourcing e outras formas de descentralização produtiva que atomizam o mercado de trabalho. Tradução de Ana Carolina Reis Paes Leme e Carolina Rodrigues Carsalade. In LEME, Ana Carolina Reis Paes et al. (Coords.). Tecnologias disruptivas e a exploração do trabalho humano. São Paulo: LTr, 2017, p. 28-43. E-book.

SILVA, Rafael Rodrigues da. Facebook será multado em US $\$ 5$ bilhões pelo escândalo da Cambridge Analytica. Canaltech, 12 jul. 2019. Disponível em: $<$ https://canaltech.com.br/redes-sociais/facebook-sera-multado-em-us-5-bilhoespelo-escandalo-da-cambridge-analytica-143991/>. Acesso em: 26 out. 2019.

STONE, Brad. As upstarts: como a Uber, o Airbnb e as killer companies do novo Vale do Silício estão mudando o mundo. Tradução de Berilo Vargas. Rio de Janeiro: Intrínseca, 2017.

SLOAN, Allan. What is Uber's stock really worth? Who knows?! The Washington Post, 1 set. 2017. Disponível em:

$<$ https://www.washingtonpost.com/business/economy/what-is-ubers-share-pricereally-worth-who-knows/2017/09/01/e496adde-8e5d-11e7-84c0-

02cc069f2c37_story.html?utm_term=.7c0cd95e245b>. Acesso em: 18 jan. 2018.

SOARES, Ronaldo. A cavalaria salvou o dia. Veja, 24 set. 2008. Disponível em: <http://veja.abril.uol.com.br/240908/p_126.shtml>. Acesso em: 10 mai. 2009.

SOROS, George. Toward a global open society. The Atlantic, jan. 1998. Disponível em: <https://www.theatlantic.com/magazine/archive/1998/01/toward-a-global-opensociety/307878/>. Acesso em: 22 out. 2018.

SOUSA, Rainer Gonçalves. Segunda revolução industrial. Brasil escola. Disponível em <http://brasilescola.uol.com.br/historiag/segunda-revolucao-industrial.htm>. Acesso em 12 de fevereiro de 2018.

SPENCER, J. Brookes et. al. Physical Science. Encyclopædia Britannica, 3 maio 2016. Disponível em: <https://www.britannica.com/science/physical-science>. Acesso em: 5 set. 2018.

STRECK, Lenio Luiz. Verdade e consenso: constituição, hermenêutica e teorias discursivas. 5. ed. São Paulo: Saraiva, 2014.

SUPIOT, Alain. O espírito de Filadélfia: a justiça social diante do mercado total. Tradução de Tânia do Valle Tschiedel. Porto Alegre: Sulina, 2014. 
SÜSSEKIND, Arnaldo; MARANHÃO, Délio; VIANA, Segadas. Instituições de direito do trabalho. Atualizada por Arnaldo Süssekind e João de Lima Teixeira Filho. Vol. I. 14. ed. São Paulo: LTr, 1994.

SUTTO, Giovanna. Amazon demite funcionários via software que mede produtividade, sem análise humana: o sistema funciona dentro dos centros de atendimento da Amazon. InfoMoney, 29 abr. 2019. Disponível em: $<$ https://www.infomoney.com.br/negocios/grandesempresas/noticia/8264444/amazon-demite-funcionarios-via-software-que-medeprodutividade-sem-analise-humana>. Acesso em: 30 abr. 2019.

TAMAJO, Raffaele De Luca. Dal lavoro parasubordinato al lavoro "a progetto". WP C.S.D.L.E. "Massimo D'Antona" 25/2003, p. 2. Disponível em: $<$ http://bancadati.italialavoro.it/bdds/download?fileName=C_21_Strumento_55_docu menti_itemName_0_documento.pdf\&uid=e6586846-f801-4a05-8ae5-fdd0f08ce1 aa> . Acesso em: 22 out. 2018.

TAVARES, Vitor. Você contrataria uma babá por aplicativo de celular? Startup paulistana acredita que sim: Sócios fazem seleção de profissionais para superar desconfiança dos pais; intenção é gerar renda extra para as profissionais. Estadão, 10 out. 2016. Disponível em: <http://pme.estadao.com.br/noticias/pme,vocecontrataria-uma-baba-por-aplicativo-de-celular-startup-paulistana-acredita-quesim,20000000215,0.htm>. Acesso em: 18 jan. 2018.

TAYLOR, Frederick Winslow. Scientific management, comprising shop management, the principles of scientific management and testimony before the special house committee, Harper \& Row, 1911; html Mark-Up: Andy Blunden. Disponível em: <https://www.marxists.org/reference/subject/economics/taylor/principles/index.htm>. Acesso em: 18 ago. 2009.).

TEIXEIRA, João Carlos. Na Constituinte, tentativa de adoção do parlamentarismo fracassou. Jornal do Senado, 25 set. 2008. Disponível em: <https://www12.senado.leg.br/noticias/materias/2008/09/25/na-constituinte-tentativade-adocao-do-parlamentarismo-fracassou>. Acesso em: 5 set. 2018.

TEUBNNER, Gunther. El derecho como sistema autopoiético. Tradução de Hjalmar Newmark. Bogotá: Universidad Externado de Colombia, 2017.

A Bukowina global sobre a emergência de um pluralismo jurídico transnacional. Tradução de Peter Naumann. Impulso, Piracicaba, UNIMEP, v. 14, № 33, 2003, p. 9-31.

TUPINAMBÁ, Carolina; GOMES, Fábio. Competência da Justiça do Trabalho. MARTINEZ, Luciano; BOUCINHAS FILHO, Jorge Cavalcanti; SILVA, Bruno Freire e. Curso de direito processual do trabalho: homenagem da Academia Brasileira de Direito do Trabalho a Christovão Piragibe Tostes Malta e Wagner D. Giglio. São Paulo: LTr, 2019. 
TURNER, Adair. A produtividade tornou-se irrelevante? Valor, 19 jul. 2017. Disponível em: <http://www.valor.com.br/opiniao/5044126/produtividade-tornou-seirrelevante>. Acesso em: 19 fev. 2018.

UBER. O guia da Uber, 17 jun. 2019. Disponível em: <https://help.uber.com/pt$\mathrm{BR} /$ riders/article/quero-solicitar-uma-viagem-com-um-motoristaespec\%C3\%ADfico?nodeld=1 aaf0913-484f-4695-9042-e61fc7613f24>. Acesso em: 17 jun. 2019.).

Não tem carro? Há uma solução. Consiga um carro e comece a dirigir. Disponível em: <https://www.uber.com/pt-BR/drive/vehicle-solutions/>. Acesso em: 23 jan. 2018.

- Informações para motoristas: como funciona o repasse de ganhos do motorista parceiro da Uber. 26 set. 2017. Disponível em: <https://www.uber.com/ptBR/blog/como-funciona-o-repasse-de-ganhos-do-motorista-parceiro-com-a-uber>. Acesso em: 2 jun. 2018.

_. Como funciona a ferramenta que verifica a identidade dos passageiros. 24 jul. 2017. Disponível em: <https://www.uber.com/pt-BR/blog/como-funciona-aferramenta-que-verifica-a-identidade-dos-passageiros-uber/>. Acesso em: 27 out. 2019.

- Código de conduta da comunidade Uber. 12 jun. 2017. Disponível em: <https://www.uber.com/legal/community-guidelines/br-pt/>. Acesso em: 20 abr. 2019.

Uber pagou R\$ 972 milhões em impostos no Brasil em 2017. 23 fev. 2017. Disponível em: <https://www.uber.com/pt-BR/newsroom/uber-pagou-972-milhoesem-impostos-no-brasil-em-2017/>. Acesso em: 18 out. 2019.

UOL. Quase um terço dos motoristas do Uber está perdendo dinheiro, diz estudo. 3 mar. 2018. Disponível em:

<https://noticias.uol.com.br/tecnologia/noticias/redacao/2018/03/03/quase-um-tercodos-motoristas-do-uber-estao-perdendo-dinheiro-diz-estudo.htm>. Acesso em: 18 maio 2019.

UNHJEM, Arne. Paul Tillich. Encyclopædia Britannica, 16 ago. 2018. Disponível em: <https://www.britannica.com/biography/Paul-Tillich\#ref124573>. Acesso em: 5 set. 2018.

URBANSITTER. Our story, 19 jan. 2018. Disponível em:

<https://www.urbansitter.com/about-us>. Acesso em: 19 jan. 2018.

USP. Informalidade no mercado de trabalho é estrutural: Para especialista da USP, o problema é resultado de escolhas feitas ainda no governo Getúlio Vargas. Jornal da USP. 1 fev. 2018. Disponível em: <https://jornal.usp.br/atualidades/informalidadeno-mercado-de-trabalho-e-estrutural/\#>. Acesso em: 2 jun. 2018.

- Startup criada por ex-alunos da Poli alcança valorização de US\$ 1 bilhão: Universidade vive momento importante com mecanismos que favorecem o 
empreendedorismo. Jornal da Usp, 24 jan. 2018. Disponível em:

$<$ http://jornal.usp.br/atualidades/startup-criada-por-ex-alunos-da-poli-alcancavalorizacao-de-us-1-bilhao/>. Acesso em: 24 jan. 2018.

VALENTE, Jonas. Governo britânico multa Facebook por violação de privacidade. Agência Brasil, 25 out. 2018. Disponível em:

$<$ http://agenciabrasil.ebc.com.br/internacional/noticia/2018-10/governo-britanicomulta-facebook-por-violacao-de-privacidade>. Acesso em: 26 out. 2018.

VARELLA, Thiago. O que o motorista de aplicativo sabe sobre o passageiro antes da viagem? UOL, 12 ago. 2019. Disponível em:

<https://www.uol.com.br/tilt/noticias/redacao/2019/08/12/o-que-o-motorista-deaplicativo-sabe-sobre-o-passageiro-antes-da-viagem.htm>. Acesso em: 27 out. 2019.

- Novo estudo diz que uso de apps como Uber pioram trânsito em cidade dos EUA. UOL, 16 maio 2019. Disponível em:

<https://noticias.uol.com.br/tecnologia/noticias/redacao/2019/05/16/novo-estudo-dizque-uso-de-apps-como-uber-piora-transito-em-cidade-dos-eua.htm>. Acesso em: 27 maio 2019.

VEJA. Uber limita turno de motoristas em 12 horas nos EUA: aplicativo contabilizará tempo ao volante e exigirá que eles se desconectem por 6 horas consecutivas após o limite ser atingido, 14 fev. 2018. Disponível em: $<$ https://veja.abril.com.br/economia/uber-limita-jornada-de-trabalho-de-motoristasem-12-horas-nos-eua/>. Acesso em: 11 out. 2019.

VELOSO, Fernando. Avanço do trabalho informal compromete retomada do crescimento: deterioração no emprego reduz produtividade do país, diz pesquisador. Folha de São Paulo, 01 maio 2019. Disponível em:

<https://www1.folha.uol.com.br/mercado/2019/05/avanco-do-trabalho-informalcompromete-retomada-do-crescimento.shtml>. Acesso em: 01 maio 2019.

VIEIRA, Nathan. Uber se recusa a contratar motoristas como funcionários na Califórnia, Canaltech, 13 set. 2019. Disponível em: <https://canaltech.com.br/juridico/uber-se-recusa-a-contratar-motoristas-comofuncionarios-na-california-149681/>. Acesso em: 14 out. 2019.

VILLAS BÔAS FILHO, Orlando. Juridicidade: uma abordagem crítica à monolatria jurídica enquanto obstáculo epistemológico. Revista da Faculdade de Direito da USP. V. 109, jan./dez. 2014, p. 281-325.

A sociologia do direito: o contraste entre a obra de Émile Durkheim e a de Niklas Luhmann. Revista da Faculdade de Direito da USP, São Paulo, v. 105, jan./dez. 2010, p. 565-563.

. Teoria dos sistemas e o direito brasileiro. São Paulo: Saraiva, 2009.

- O direito na teoria dos sistemas de Niklas Luhmann. São Paulo: Max Limonad, 2006. 
VILLANOVA, Ana Luisa Ilha. Modelos de negócio na economia compartilhada: uma investigação multi-caso. Rio de Janeiro, 2015, 126 f. Dissertação (Mestrado em Gestão Empresarial)-Fundação Getúlio Vargas, Rio de Janeiro, 2015. Disponível em:

<http://bibliotecadigital.fgv.br/dspace/bitstream/handle/10438/15184/VERS\%c3\%830 \%20FINAL\%20DISSERTA\%c3\%87AO\%20-

$\% 20$ Ana\%20Luisa\%20Villanova.pdf?sequence=1\&isAllowed=y>. Acesso em: 12 jul. 2018.

VULETA, Christina. UrbanSitter founder proves, even in Silicon Valley, you can combine motherhood and high growth. Forbes, 12 maio 2017. Disponível em: $<$ https://www.forbes.com/sites/break-the-future/2017/05/12/urbansitter-founderproves-that-even-in-silicon-valley-you-can-combine-motherhood-and-highgrowth/\#5191f6e11792>. Acesso em: 19 jan. 2018.

WAINER, Jacques. O paradoxo da produtividade. In: RUBEN, Guilhermo et al. (Orgs.). Informática, organizações e sociedade no Brasil. São Paulo: Cortez Editora, 2003. Disponível em: <http://www.ic.unicamp.br/ wainer/papers/final-paradoxo.pdf>. Acesso em: 19 fev. 2018.

WAKKA, Wagner. Brasil adere ao protesto mundial contra Uber e motoristas devem parar amanhã (8). Canaltech, 7 maio 2019. Disponível em:

<https://canaltech.com.br/apps/brasil-adere-ao-protesto-mundial-contra-uber-emotoristas-devem-parar-amanha-8-138671/>. Acesso em: 26 maio 2019.

WALL, Matthew. O que é o $5 \mathrm{G}$ e como ele pode mudar as nossas vidas. BBC Brasil, 24 jul. 2018. Disponível em: <https://www.bbc.com/portuguese/geral44936142>. Acesso em: 10 out. 2019.

WESTMAN, Robert S. Nicolaus Copernicus. Encyclopædia Britannica, 20 maio 2018. Disponível em: <https://www.britannica.com/biography/Nicolaus-Copernicus>. Acesso em: 5 set. 2018.

WOLL, Cornelia. Regulation. Encyclopædia Britannica, 11 nov. 2016. Disponível em: <https://www.britannica.com/topic/regulation>. Acesso em: 15 dez. 2018.

WOOD JR., Thomaz. Fordismo, toyotismo e volvismo: os caminhos da indústria em busca do tempo perdido. RAE-Revista de administração de empresas, vol. 32, n. 4, 1992. Disponível em: <http://www.fgv.br/rae/artigos/revista-rae-vol-32-num-4-ano1992-nid-44275/>. Acesso em: 13 fev. 2018.

WOOLF, Alex. Uma nova história do mundo. Tradução de Maria Beatriz de Medina. São Paulo: M.Books do Brasil, 2014.

ZA. MPT conclui que há vínculo de trabalho em aplicativos como Uber e quer ações coletivas. Banda B, 13 jul. 2017. Disponível em:

<https://www.bandab.com.br/geral/mpt-conclui-que-ha-vinculo-de-trabalho-emaplicativos-como-uber-e-quer-acoes-coletivas/>. Acesso em: 17 ago. 2019. 
ZIPPERER, André Gonçalves. A multiterceirização e a subordinação jurídica. A intermediação de mão de obra a partir de plataformas digitais e a necessidade de tutela modular do Direito do trabalho. 2018, $251 \mathrm{f}$. Tese (Doutorado em Direito)Pontifícia Universidade Católica do Paraná, Curitiba, 2018. Disponível em:

$<$ http://www.biblioteca.pucpr.br/pergamum/biblioteca/img.php?arquivo=/00006c/0000 6c14.pdf>. Acesso em: 16 maio 2019.

ZYLBERSTAJN, Hélio. A economia "gig": um olhar adiante.

Disponível em:

<http://www.mascaro.com.br/boletim/boletim_193/a_economia_gig_um_olhar_adiant e.html>. Acesso em: 25 abr. 2017. 